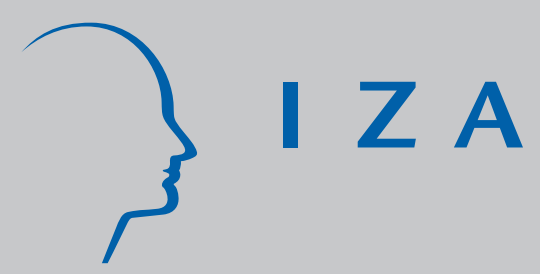

IZA DP No. 550

The Impact of Local Labour Market Conditions on Participation in Further Education in England

Damon Clark

August 2002 


\title{
The Impact of Local Labour Market Conditions on Participation in Further Education in England
}

\author{
Damon Clark \\ IZA Bonn \\ Discussion Paper No. 550 \\ August 2002 \\ IZA \\ P.O. Box 7240 \\ D-53072 Bonn \\ Germany \\ Tel.: +49-228-3894-0 \\ Fax: +49-228-3894-210 \\ Email: iza@iza.org
}

This Discussion Paper is issued within the framework of IZA's research area The Future of Labor. Any opinions expressed here are those of the author(s) and not those of the institute. Research disseminated by IZA may include views on policy, but the institute itself takes no institutional policy positions.

The Institute for the Study of Labor (IZA) in Bonn is a local and virtual international research center and a place of communication between science, politics and business. IZA is an independent, nonprofit limited liability company (Gesellschaft mit beschränkter Haftung) supported by the Deutsche Post AG. The center is associated with the University of Bonn and offers a stimulating research environment through its research networks, research support, and visitors and doctoral programs. IZA engages in (i) original and internationally competitive research in all fields of labor economics, (ii) development of policy concepts, and (iii) dissemination of research results and concepts to the interested public. The current research program deals with (1) mobility and flexibility of labor, (2) internationalization of labor markets, (3) welfare state and labor market, (4) labor markets in transition countries, (5) the future of labor, (6) evaluation of labor market policies and projects and (7) general labor economics.

IZA Discussion Papers often represent preliminary work and are circulated to encourage discussion. Citation of such a paper should account for its provisional character. A revised version may be available on the IZA website (www.iza.org) or directly from the author. 
IZA Discussion Paper No. 550

August 2002

\title{
ABSTRACT
}

\section{The Impact of Local Labour Market Conditions on Participation in Further Education in England*}

Over the past 30 years, participation in Further Education (FE) in England has been markedly counter-cyclical. What is more, it has yet to increase beyond the peak of $70 \%$ reached in 1993, much to the concern of policy-makers. An obvious explanation for these facts is the availability of labour market opportunities, as measured by youth unemployment. Other things equal, the higher is youth unemployment, the more inclined young people will be to participate in FE. To assess this claim, we construct a 20 -year panel of regional-level data. In line with this simple story, we find youth unemployment effects that are at least twice as large as those previously estimated, and that can explain the absence of any post-1993 increase, at least for boys. Other interesting findings concern the role of national returns to participation for boys, and cohort size for girls.

JEL Classification: J24, J31, I21, I28

Keywords: $\quad$ human capital, further education, local labour markets

\author{
Damon Clark \\ IZA \\ P.O. Box 7240 \\ D-53072 Bonn \\ Germany \\ Tel.: +492283894304 \\ Fax: +492283894210 \\ Email: clark@iza.org
}

\footnotetext{
*This paper has greatly benefited from discussions with Steve Nickell. Christian Dustmann, Mary Gregory, Richard Layard, Hilary Steedman, Anna Vignoles and seminar participants at LSE and DES also provided useful comments. I am very grateful to the DES for providing me with data, and to Gavan Conlon, Tanvi Desai, Marco Leonardi, and Jonathan Wadsworth for helping to construct various series.
} 


\section{Introduction}

As part of the landmark Education Act of 1944, local education authorities in England were obliged to provide Further Education (FE) for all of those young people reaching the minimum school-leaving age (then 14) and wishing to receive it. In the late 1940 s and early 1950 s, roughly $10 \%$ of those reaching the schoolleaving age took up this option, the majority leaving school to find work. By 2001, participation in FE amongst those reaching the minimum school-leaving age (now 16) was roughly $70 \%$.

Interestingly, as seen in Figure 1, the increase in FE participation over the post-war period has been far from linear. Rather, participation increased linearly until the 1970s, but thereafter followed a procyclical pattern, with three episodes of sharp increase followed by stagnation or decline - in the mid-1970s, the early 1980s and the early 1990s. Indeed, participation is yet to reach the peak achieved in 1993.

Why should we be interested in these phenomena? First, as Becker (1964) argued, the participation decision can be viewed as an economic decision, more specifically an investment decision. As such, it is interesting to investigate the calculations that young people make when choosing whether or not to participate in FE. As Freeman (1986) put it, 'How well does the economic model of investment in human capital explain individual demands for education and thus the supply of educated labour?' (p. 357).

In the contemporary English context, the answer to this question of what drives participation is also of profound policy importance. That is because recent education policy - a concerted drive to increase certain education 'inputs' and 'outputs' - has been less than completely successful, at least in terms of the targets that successive Governments have set for themselves. ${ }^{1}$ This failure is in large part due to the post-1993 slowdown in participation growth. ${ }^{2}$

For both the National Learning Targets and the HE participation targets to be reached, significant increases in FE participation are therefore required. This fact has not been lost on the British Government, and an Educational Maintenance Allowance (EMA) to be paid to all school-leavers from low-income households that choose to participate in FE forms the centrepiece of the Government's plan to increase the FE participation rate as spelt out in the 2002 Comprehensive Spending Review. Yet whilst this policy has been carefully pi-

\footnotetext{
${ }^{1}$ The output metric takes the form of the 'National Learning Targets'. These specify target proportions of young people to have surpassed certain qualification thresholds - most prominently 'NVQ level 2' - by certain dates. The input metric is the rate of participation in higher education (HE), and the Government's much-discussed commitment to raise this to $50 \%$ of all young people by 2010 .

2 The fact that FE participation peaked in 1993 will have contributed to the slowdown in qualification attainment. At $74.8 \%$ in 2001, it is well below the target level of $85 \%$ by 2002 . Regarding HE participation, even when the Government's preferred (broader) definition of participation is employed (this inflates the 2001 figure from $33 \%$ as measured using the Age Participation Index (API) to $41 \%$ ), the $50 \%$ figure looks more like a distant ambition than a realistic target (the figure of $41 \%$ was given by David Normington of the DfES to the House of Commons Education and Skills Select Committee, 30 January 2002).
} 
loted in recent years, it is in one important sense a policy that has been made in a vacuum. That is, EMAs are being offered as part of the remedy to an illness that has yet to be satisfactorily diagnosed: why has participation not increased since 1993 ?

Generally speaking, factors put forward to explain participation trends fall into two broad categories: those that vary at the individual or micro level such as exam achievement and family income - and those that vary at an aggregate or macro level such as unemployment. In research based on micro (typically cross-sectional) data, a strong positive correlation has been found between exam achievement and participation. At an aggregate level, this suggests - as illustrated in Figure 2 - that exam achievement can explain the broad trend in participation. Yet the the steady increase in exam achievement seems incapable of explaining either of the first two cyclical episodes (in the mid-1970s and the early-1980s) or the absence of any participation increase since 1993.

A more promising explanation for these phemomena is the state of the youth labour market, coupled with the assumption that school-leavers are more likely to participate in FE when unemployment is high. In support of this story, Figure 2 illustrates the very tight correspondance between the sharp participation increases of the mid-1970s and early 1980s and the increased unemployment induced by the recessions experienced during these periods. ${ }^{3}$ In a similar vein, we might speculate that the absence of any post-1993 participation trend is due to modest improvements in exam achievement being offset by large falls in unemployment. This contrasts with the 1988-1993 episode, when both improved exam achievement and increased unemployment may have served to dramatically increase participation.

Whilst this simple explanation fits all of the facts, the previously estimated participation-unemployment correlation is too weak to explain more than a small part of these observed trends. Although this casts doubt on the plausibility of this simple story, there are reasons for questioning these estimated correlations. In particular, since the effects of aggregate variables are hard to identify in crosssectional data, our knowledge of the participation-unemployment relationship is based largely on correlations observed over time. These are typically based on a small number of observations and may be distorted by other, omitted, timevarying determinants of participation. For example, as we discuss below, there have over the 20-year period that we consider, been a large number of policy changes affecting the context in which the participation decision is taken.

In this paper, we analyse the effects of youth unemployment (and other aggregate variables) on participation using a 20 -year panel of regional data. Exploiting the variation in participation and these aggregate variables over time and between regions allows us to control for omitted determinants of participation via the inclusion of a full set of region and year dummy variables. In addition, the increased number of observations afforded by our regional panel

${ }^{3}$ Although we use youth unemployment data in our empirical analysis, we have these series from 1976 only. Figure 2 therefore uses an overall unemployment series. Of course the two are highly correlated. 
should enable us to identify more robust relationships between these aggregate variables and participation. Our key finding is that youth unemployment has a crucial bearing on participation, particularly for boys. Indeed, the effects are estimated to be at least twice as large as those previously found, and in line with the above story, broadly explain the recent slowdown in participation growth. For girls, the effects are weaker, and so a part of the recent trend remains unexplained. Other interesting results include strong effects of national rates of return to participation on boys' participation and large negative effects of cohort size - a proxy for supply constraints - on girls' participation.

The remainder of the paper is organised as follows. We begin with a discussion of the related literature (section 2), and proceed to outline our estimation strategy (section 3). We then discuss our regional data (section 4) before presenting our empirical results (section 5). Section 6 discusses additional evidence in support of an unemployment explanation, and section 7 concludes with a discussion of the policy implications of our findings.

\section{Related Literature}

Although the literature related to our study is broadly empirical, it helps to begin by considering the theoretical framework underpinning these papers.

\section{Theoretical Framework}

The first paper to deal explicitly with the forces driving the FET participation decision - more generally, the decision to invest in education - was Becker (1967). In a static context, Becker drew downward-sloping 'demand' (marginal return) and upward-sloping 'supply' (marginal cost) curves as functions of the dollars spent on education. He argued that decreasing marginal returns reflected the physical capacity of human memory and that increasing marginal costs reflected a hierarchy of finance, whereby students borrowed first from their parents and then from more expensive commercial lenders.

Ben-Porath (1967) set Becker's problem in a dynamic context, treating the issue as one of time allocation. In dropping Becker's assumption of education as a 'final good', he was able to rationalise some commonly observed features of educational investment, including the concentration of investment at the beginning of the career. In turn, Ben Porath's model was refined during the 1970s and 1980s, as interest centred on estimates and interpretations of the 'returns to school'. Investment at the beginning of the career became an assumption, and a closed-form to solution to this 'optimal years of schooling' problem was derived (see Rosen (1977) and Willis (1986)).

Whilst these models have yielded valuable insights into various issues surrounding the returns to school (see Card (1999)), they are an overly restrictive foundation on which to base an understanding of the participation decision. A more appropriate model is discussed by Card and Lemieux (2000). This is aimed squarely at an empirical understanding of the forces driving participation and relaxes many of the assumptions previously made. 
On the cost side, tuition costs and earnings whilst in education are allowed to influence the years of schooling chosen. Regarding benefits, a temporary increase in unemployment is shown to increase the optimal schooling length. The model is also extended to allow for different preferences regarding school versus work (utility- rather than income-maximisation), and the authors stress this as a potentially important channel through which family background affects participation.

On the back of this theoretical discussion, Card and Lemieux (2000) attempt an empirical investigation of the stagnation of participation in the US since the late 1960s (especially amongst males aged 18-21). Since this is the empirical approach most closely related to ours, and since it provides a useful tool for describing the British literature, we briefly review this work in the context of a brief discussion of the US literature.

\section{Empirical Evidence from the US}

The participation analysis of Card and Lemieux (2000) is based on the following econometric model (which they argue can be viewed as a linear approximation to the solution of the maximisation problem described above):

$$
P\left(S_{i r t}>k\right)=P\left(\alpha+\beta X_{i r t}+\delta Z_{r t}+\gamma W_{t}\right)
$$

where $S_{\text {irt }}$ denotes the number of years of post-compulsory schooling desired (and chosen) by individual $i$ in region $r$ in year $t .{ }^{4}$ The sets $X_{i r t}, Z_{r t}$ and $W_{t}$ partition the variables considered in the theoretical discussion into three groups: those such as family background that vary at the individual level (included in the set $\left.X_{i r t}\right)$, those such as unemployment that vary at the regional level $\left(Z_{r t}\right)$ and those that vary at the national level $\left(W_{t}\right)$, such as the return to schooling.

Card and Lemieux (2000) follow a three-step estimation strategy. First, they use a time series of cross-sectional data to estimate logistic regression models of the probability of participating in the $k^{\prime}$ th year, $P\left(S_{i r t}>k\right)$, controlling for the omitted $Z_{r t}$ and $W_{t}$ variables by including of a full set of unrestricted region-year dummy variables (denoted $R T$ ):

$$
P\left(S_{\text {irt }}>k\right)=P\left(\alpha+\beta X_{\text {irt }}+R T>k\right)
$$

Having estimated the coefficients on the individual-level variables $(\beta)$ this way, they then turn to the coefficients on the regional-level variables $(\delta)$. These are estimated from a version of equation (1) aggregated up to the regional level: ${ }^{5}$

$$
\overline{P_{r t}}=\alpha+\beta \bar{X}_{r t}+\delta Z_{r t}+R+T+v_{r t}
$$

\footnotetext{
${ }^{4}$ Card and Lemieux (2000) refer to 'enrolment rates', 'states' and 'cohort effects'. We use the terms 'participation rates', 'regions' and 'year effects' to maintain consistency with the British literature.

${ }^{5}$ They estimate this equation by weighted least squares, where the weights are the number of observations in the region-year cell.
} 
where $\overline{P_{r t}}$ and $\overline{X_{r t}}$ are regional averages of participation rates and individuallevel characteristics. The inclusion of region and year dummy variables (denoted $R$ and $T$ respectively) is intended to capture the omitted $W_{t}$, as well as any omitted $X_{i r t}$ and $Z_{r t}$ (to the extent that these can be decomposed into a permanent region-specific component and a time-varying aggregate component).

Turning finally to the coefficients on the national-level variables $(\gamma)$, Card and Lemieux (2000) estimate these by ordinary least squares from a version of equation (1) aggregated up to the national level:

$$
\overline{P_{t}}=\alpha+\beta \bar{X}_{t}+\delta \bar{Z}_{t}+\gamma W_{t}+T R E N D+\epsilon_{t}
$$

where $\overline{P_{t}}, \overline{X_{t}}$ and $\overline{Z_{t}}$ are national averages of participation rates, the individuallevel variables and the regional-level variables respectively. Overall, their results highlight the importance of cohort size (a measure of supply constraints) and the return to schooling in explaining the observed trends.

Other papers focussing on participation in the US can be slotted into one of two broad categories. Corresponding to versions of equation (2) is a large literature which attempts to test whether estimated correlations between participation and family income are due to credit constraints or unmeasured parental and child characteristics. Cameron and Heckman (1998) and Shea (2000) are important contributions to this 'Does Money Matter?' literature. Corresponding to equation (4) is an older time series literature reviewed by Freeman (1986) that attempts to explain the broad determinants of participation, with special focus on the elasticity of participation with respect to the rate of return to schooling. Two papers lying outside of this dichotomy are Kane (1994) and Betts and McFarland (1995). Kane (1994) investigates the decline in college participation amongst blacks between 1980 and 1984, and the subsequent rebound. Using a time series of cross-sections of 18-19 year old youths over the period 1973-1988, Kane (1994) estimates a version of equation (2) (with region and time dummies but not interactions) and finds that family income and parental education have strong positive effects on participation, whilst there are no discernible effects from regional unemployment. Betts and McFarland (1995) exploit enrollment data for approximately 800 community colleges across a 20 -year period and find large local labour market effects in an equation that includes college, region and year dummy variables. ${ }^{6}$

\section{Empirical Evidence from Britain}

Unlike the US literature, which deals with participation decisions made at various ages, the bulk of the British literature focuses on the FE participation decision made at the end of compulsory schooling. ${ }^{7}$ One strand of this literature

\footnotetext{
${ }^{6}$ One paper focussing on Spain is Petrongolo and San Segundo (2002). They use an approach similar to that of Kane (1994) and use three waves of cross-sectional data to show that local labour markets have strong effects on the enrollment behaviour of 16 year olds.

${ }^{7}$ A recent exception is Chevalier and Lanot (2001). They are interested inter alia in the impact of family income on the propensity to participate in higher education. They find a
} 
uses individual-level data to investigate the determinants of participation. These contributions - which include Rice (1987), Micklewright (1989), Micklewright, Pearson, and Smith (1990) and Rice (1999) - estimate versions of equation (2). ${ }^{8}$

Rice (1999) is based on the largest and the most recent sample of students. She finds that whilst school type, ethnicity and family background (especially parental socio-economic group) have an impact on participation, the largest effect comes from exam achievement. For a school-leaver with a base set of characteristics, the predicted probability of participation increases from 0.084 (0.172) for boys (girls) with no exam achievements to 0.869 (0.884) for boys (girls) with greater than five GCSE passes at grades A-C.

One problem with the YCS data used in the Rice (1999) study is the absence of any family income measure. At the cross sectional level, our knowledge of the effect of family income on participation therefore rests on the estimates provided by Rice (1987) and Micklewright (1989). Whilst Rice (1987) finds significant effects for girls but not boys using Family Expenditure Survey (FES) data, Micklewright (1989) uses the National Child Development Study (NCDS) and is therefore able to include a far larger number of control variables, including exam achievement. He finds that income has no effect on the participation of boys and only small effects on that of girls. More recent evidence in favour of an income effect comes from the Government's EMA pilot study. Introduced in September 1999, this provided a weekly allowance and termly bonus to young people from low-income households that choose to participate in FE. An evaluation conducted by Ashworth, Hardman, Lui, Maguire, Middleton, Dearden, Emmerson, Frayne, Goodman, Ichimura, and Meghir (2001) shows that the average gain in the pilot area is $5 \%$, with effects greater for boys than girls (contrary to the evidence reviewed above).

An interesting aspect of the Rice (1999) paper is the use to which the multiple waves of YCS data (1988, 1990 and 1991) are put. In particular, Rice (1999) estimates a version of equation (2) that includes local unemployment rates and finds that unemployment has fairly strong effects, especially for boys with low levels of exam achievement. There are, however, important econometric issues associated with the inclusion of grouped variables in individual-level equations. In particular, as argued by Moulton (1990), when there are components of variance not attributable to measured individual-level characteristics or the measured grouped variable (local unemployment rates in this case), the conventionally estimated standard errors may be seriously downward-biased, with the size of the bias an increasing function of the average group size and the intra-group error correlation.

Since Rice (1999) has unemployment data at only the county level (there

positive effect even conditioning on detailed test scores. Another exception is Pissarides (1982) who provides a time series analysis of participation in higher education (HE).

${ }^{8}$ In an interesting paper based on a rich individual-level dataset, Andrews and Bradley (1997) consider a wide range of choices at 16, rather than the simple one of whether or not to participate in FE full-time. Although their careful study shows that the data rejects this simple dichotomy, since our regional level data take this simple form, we focus on those papers that consider this decision. 
are roughly 50 counties in England and Wales), and since the number of observations is large (approximately 25,000 each for boys and girls), average group size is very large (approximately 500). ${ }^{9}$ Regarding the intragroup error correlation, any problems here will be exacerbated by the fact that county-level dummy variables are not included in the estimated model. This also creates the potential for ommitted variable bias, since any county-level variables correlated with both participation and the county unemployment rate will bias estimates of the unemployment effect. Although Rice (1999) argues that the model with regional dummies performs better overall, it is difficult to interpret the unemployment effects in this context. Micklewright, Pearson, and Smith (1990) also estimate the effects of unemployment using grouped unemployment variables in an individual-level participation equation, although they find that unemployment (measured at the regional level) has no effect on participation.

A more traditional means of estimating the participation effects of unemployment is via the use of time series data and an estimated equation such as (4). In the British context, these contributions include McVicar and Rice (2001) and Whitfield and Wilson (1991). Building on the pioneering analysis of Pissarides (1981), Whitfield and Wilson (1991) extend his model over the longer period 1957-1986. They find that that participation is reduced by the avilability of youth training scheme (YTS) places and increased by both the return to graduation from higher education and the claimant count rate of unemployment (elasticities of 0.3 and 0.1 respectively when evaluated at 1985 sample means). Using data over a longer period (1954-1996), McVicar and Rice (2001) find smaller effects from differently measured versions of all three variables. ${ }^{10}$ Unlike Whitfield and Wilson (1991) however, McVicar and Rice (2001) also examine measures of exam achievement, family income and higher education (HE) participation. Whilst they find - in line with Micklewright (1989) - that family income has almost no impact on participation, both exam achievement and $\mathrm{HE}$ participation have large positive effects, and can jointly explain much of the rapid participation growth witnessed over the period 1988-1994.

How should we interpret these differences in results? In part they will reflect the different variables considered by the two studies, as well as the different estimation techniques employed (McVicar and Rice (2001) investigate the long-

\footnotetext{
${ }^{9}$ With group sizes of even smaller magnitude, Moulton (1990) considers an example in which an intraclass error correlation of just 0.032 produces conventionally estimated standard errors that are downward biased by a factor of 3.7. Although the biases involved in the Rice (1999) estimates may be less or indeed more severe, biases of this magnitude would render all of the unemployment coefficient estimates insignificant.at the $5 \%$ level.

${ }^{10} \mathrm{McVicar}$ and Rice (2001) uses a measure of youth training that encompasses more than YTS, a measure of youth rather than overall unemployment and the ratio of non-manual to manual wages. Although McVicar and Rice (2001) do not report an unemployment elasticity, when evaluated at the 1985 participation rate reported by Whitfield and Wilson (1991) (44\%, endnote 3$)$, and the youth unemployment rate taken from our data $(22 \%)$, the long-run elasticity turns out to be $\frac{0.1229 *(1-0.44)}{1-0.22}=0.088$ for males (coefficient estimate taken from Table $1 \mathrm{~b}$, column 2.i; participation and unemployment entered in the form $\left.\ln \left(\frac{X}{1-X}\right)\right)$ and lower for females.
} 
run cointegrating relationships using full information rather than single-equation methods). Yet they may also reflect the sensitivity of results to assumptions made about the context in which the participation decision is taken. Since this context has changed considerably over the post-war period, this problem may be severe. To illustrate, McVicar and Rice (2001) use YTS participation to explain FE participation, on the basis that the widespread availability of YTS places in the early 1980s may have increased the opportunity costs of participation. As McVicar and Rice (2001) note, this assumes that the supply of YTS places is inelastic, and so they experiment with a series of step dummy variables designed to tackle this problem. On the other hand, McVicar and Rice (2001) use HE participation to explain the FE participation. This implies either that $\mathrm{HE}$ demand is inelastic - so that changes in HE participation reflect opportunities available to young people - or that changes in HE participation have direct consequences (via peer effects) for the FE participation rate.

Both the YT and HE participation assumptions are plausible. Yet they are an arbitrary foundation on which to build empirical models of participation. More worrying still are the myriad policy changes not considered in either analysis. Those taking place since 1976 (the first year of our sample) are charted in Table 1. They include four overhauls of work-based training options, major changes to both the academic and vocational courses available to FE students, a change in the funding regime governing FE institutions and therefore their incentives to recruit students, a major change to the benefit regime facing non-FE participants and and an overhaul of the curriculum studied in school. The fact that time series studies cannot control for all of these changes without reducing degrees of freedom to the point where estimated relationships are no longer robust underlines the advantages offered by our regional panel dataset.

\section{Empirical Strategy}

Since the main focus of our paper is the effect of regional-level variables on FE participation, our basic strategy is to estimate a version of equation (3). Although this suggests a close connection to the Card and Lemieux (2000) analysis, there are some important differences between the two approaches. First, as already noted, school-leavers in England sit public examinations at the end of their final compulsory year. For the most part, our basic analysis assumes that the outcome of these examinations is exogenous to the participation decision and conditions the participation decision on school examination achievement. However, we also relax this assumption and consider some 'reduced form' models of participation.

Another important difference between England and the US relates to tuition costs. Since there are no direct cost to participating in FE in England, we do not consider 'price' measures such as tuition costs. Instead, we allow for the possibility that some students are subsidised by their parents through the FE period, and investigate the effect of family income on participation. This is particularly interesting given the EMA policy and the lack of convincing 
microeconometric evidence on the question of the family income effect.

In common with Card and Lemieux (2000) we include a measure of cohort size as a proxy for possible supply effects. Although we noted in the Introduction that school-leavers have the legal right to participate in FET if they choose to do so, it may be that for larger cohort sizes, popular courses become oversubscribed or the quality of $\mathrm{FE}$ received decreases. The basic equation to be estimated can therefore be written as follows:

$$
\begin{aligned}
\overline{P_{r t}}= & \beta_{0}+\beta_{1} \overline{E X A M_{r t}}+\beta_{2} \overline{I N C O M E_{r t}}+\beta_{3} U N Y O U T H_{r t}+ \\
& \beta_{4} U N E D N_{r t}+\beta_{5} R E T U R N_{r t}+\beta_{6} C O H O R T_{r t}+R+T+\nu_{r}\left(3^{\prime}\right)
\end{aligned}
$$

where the upper bars denote regional averages and $R$ and $T$ are region and year dummy variables designed to capture any omitted individual-level and regionallevel variables. Since the related literature finds that several factors affect the participation behaviour of boys and girls diffferently, our approach is to estimate separate equations by sex.

The dependent variable in this equation is a proportion, and so we might consider transforming this equation and taking the log odds ratio of participation as our dependent variable. To facilitate the interpretation of our results, we choose not to do this, and instead follow Card and Lemieux (2000) in estimating our models by weighted least squares (to take account of the different schoolleaving populations across regions). Experiments show that this decision has almost no impact on our basic estimates.

Regarding the explanatory variables, we would like to measure unemployment by age and education level in order to assess the effects of different types of unemployment on participation. Unfortunately, the best we can do is construct a measure of youth unemployment across all education groups, and a measure of unemployment by education level across all age groups. One problem with the youth unemployment measure is that it is arguably endogenous (youth unemployment may be low when participation is high). Since this would induce a negative correlation between the two variables, we do not worry about this problem, and instead treat our estimates as lower bounds to the true effects. The unemployment rates by education level are problematic in a different respect. Like our income and return measures, they are derived from survey data and hence subject to sampling error. We deal with this problem by instrumenting these variables using their lagged values (which we expect to be correlated with the true component but not the sampling error). Within the context of this basic approach, we then investigate a number of issues.

\section{Region-Specific Trends}

The reliability of estimates derived from equation (3') depends on the degree to which region and year dummy variables can control for the effects of variables that are omitted from this equation. Of particular concern may be the fact that some variables may change differentially across regions over time. We know for example that there was considerable migration into the South-East of England 
over the period that we consider. We deal with this problem by estimating versions of equation (3') that are augmented to include region-specific trends. This is the approach taken by Bell, Nickell, and Quintini (2000) in the context of regional wage equations.

\section{Reduced Form Models}

As noted above, our basic assumption is that examination achievement is exogenous to the participation decision. We can justify this on the basis that these results will reflect the effort exerted over eleven years of education, in addition to innate ability and other school 'inputs' beyond the control of the schoolleaver. On the other hand, it could be argued that examination achievement is endogenous to the participation decision in the sense that students deciding to participate may try to obtain better results, and students deciding not to participate my exert no effort at all. If this is the case, exam achievement will be driven inter alia by the expected returns to participation in post-compulsory education. We check this possibility by estimating 'reduced form' models of participation in which we do not include exam achievement measures. The estimates derived can then be interpreted as the 'full' effects of these other variables on participation.

\section{Regional versus National Factors in Expectations Formation}

Since the level of youth unemployment determines the current cost of not participating in education, the appropriate measure of youth unempoyment is local (i.e. regional) youth unemployment. Regarding the longer-term benefits of participation, these may be realised in the local region, or if the school-leaver eventually leaves the region, in another region. For this reason, it is unclear whether regional, or for example, national estimates of returns and unemployment by education are relevant to the formation of expectations. Indeed, even if school-leavers are interested in regional values of these variables, it may be that they have accurate information at only the national level. In that case, small regional estimates may lead us to incorrectly conclude that these variables have no impact on the participation decision. We investigate this issue by estimating versions of equation (4) in which the dependent variable is the year dummy variables estimated from equation (3') and national returns and unemployment levels by education are regressors.

\section{Decomposing Changes over Time}

As a final exercise, we wish to consider the importance of the variables considered in explaining observed participation trends. To that end, we aggregate up to the national level and note that:

$$
\begin{aligned}
\Delta \bar{P}_{t=1, t=0}= & \beta_{1} \Delta \overline{\operatorname{EXAM}}_{t=1, t=0}+\beta_{2} \Delta \overline{\operatorname{INCOME}}_{t=1, t=0}+\beta_{3} \Delta \overline{U N Y O U T H}_{t=1, t=0} \\
& \beta_{4} \Delta \overline{U N E D N}_{t=1, t=0}+\beta_{5} \Delta \overline{\operatorname{RETURN}}_{t=1, t=0} \\
& +\beta_{6} \Delta \overline{\operatorname{COHORT}}_{t=1, t=0}+\left(\widehat{T}_{t=1}-\widehat{T}_{t=0}\right)+\left(\widehat{v}_{t=1}-\widehat{v}_{t=0}\right)
\end{aligned}
$$


where $\Delta \bar{X}_{t=1, t=0}$ is the change in the national average value of variable $\mathrm{X}$ between periods $t=1$ and $t=0$. Given this relationship, we can decompose changes in participation between any two periods $(t=1$ and $t=0)$ into those induced by changes in the different variables considered in equation (3)', those associated with the difference in estimated year dummy variables and that which remains unexplained. Corresponding to the model augmented to include region-specific trends, we also consider a decomposition that includes a (population) weighted average of the region-specific trends.

\section{Data}

In this section we describe how we construct our regional panel data, beginning with a description of the dependent variable.

\section{Participation Rates}

The Data Appendix describes in detail how the dependent variable is constructed. Participation rates are defined as the proportion of the maintained school cohort (the approximately $95 \%$ of students in state-funded schools) counted as being in FE in the January of the academic year following the year in which the cohort left school. For example, participation amongst the maintained school cohort finishing compulsory schooling in June 1991 is measured as the proportion of this cohort registered in education in January 1992. Since some students will drop out of further education between the start of the academic year (September) and January, these will not be picked up by our measure. Equally, our measure will not be the same as the proportion of students that actually complete courses. The north-west quadrant of Figure 3 graphs FE participation rates by sex over the sample period 1976-1996. As we saw in Figures 1 and 2, there were two episodes of sharply increasing participation over this period the first in the early 1980 s and the second in the early 1990s. These patterns are evident for both boys and girls, although participation is generally higher amongst girls.

\section{Exam Achievement}

The Data Appendix also describes how the exam achievement series was constructed. Achievement is broken down into four mutually exclusive categories: those with greater than five O-level/GCSE passes at A-C level; those with between one and four passes at A-C level; those with one or more passes at D-F level and those with no passes. As the north-east and south-west quadrants of Figure 3 show, the effect of replacing O level with GCSE courses (the first GCSE examinations were taken in 1988) was to increase the proportion obtaining five or more higher grade passes at the expense of the proportion of those with some lower grade passes. The level of achievement amongst girls is consistently higher than that amongst boys over the period considered, and the post-1988 increase is also sharper. 


\section{Parental Income}

The other individual-level variable that we consider is income. We use as our measure of income the average real equivalised household income amongst families with children in every region and every year obtained from the Family Expenditure Survey (FES). Trends in this variable are plotted in the south-east quadrant of Figure 3.

\section{Youth Unemployment}

Our measure of youth unemployment is the proportion of 18-19 year olds in every region and every year recorded as claimant count unemployed (typically recorded in the first quarter of the year). Although the exact construction of this series is discussed in more detail in the Data Appendix, it is important to note that the demominator used here is the relevant population measure, rather than the sum of claimant count unemployed and workforce jobs (which cannot be broken down by age and region). Although this may introduce problems associated with trends in inactivity within and between regions, the inclusion of region and time dummies should take care of this. Even in the event of there being some region-specific inactivity trends, these would be controlled for in the estimates that we report that include region-specific trends. Not surprisingly, as seen in the north-west quadrant of Figure 4, this series is strongly countercyclical, and increased dramatically during the recessions of the early 1980s and early 1990s. It is also apparent from Figure 4 that the variation of youth unemployment over the cycle is more marked for boys than girls.

\section{Unemployment by Education Level}

In order to capture the benefits to participation in terms of lower unemployment, we use the Labour Force Survey (LFS) to construct unemployment rates by education for the whole working age population in each region and each year (typically recorded in the second quarter of every year). These are defined according to the ILO rather than the claimaint count definition (those actively seeking work rather than those claiming benefits). Since we do not have data for 1980 and 1982 in the LFS, we average across the years before and after.

Although our basic aim is to compare the unemployment rate amongst those that participated in FE with that amongst those that did not, the group that participates is a heterogenous one, with participants differing in terms of the type of institution attended (school, sixth form, further education college), and also the type of qualification studied for (A level, vocational qualifications, GCSE). Since the latter seems particularly important, we choose to divide the group of school-leavers into those that do not participate in FE, those that participate and study for a vocational qualification, and those that participate and study for an academic qualification. In fact, since the LFS only records information regarding highest qualification attained, we have to make some assumptions as to which route an individual followed to their highest qualification in order to form these three groups. These assumptions are outlined in Table 2 and the 
north-east quadrant of Figure 4 graphs the three series. As we might expect, unemployment rates are highest amongst the leavers, and lowest amongst those that participated in FE and studied for an academic qualification. All three series move with the cycle.

\section{Returns to Participation}

We obtain an estimate of the return to FE participation using the General Household Survey (GHS). We again proceed by classifying people into those that did not participate in FE, those that participated and studied for an academic qualification, and those that participated and studied for a vocational qualification. Again, we only have information on highest qualification from the GHS, and so we make some assumptions regarding the route to the highest qualification (see Table 2).

Given these groups, we estimate the economic returns to participation by pooling all full-time workers in region $r$ in year $t$ and estimating a log-earnings equation of the following form:

$$
\begin{aligned}
\ln w_{i r t}= & \beta_{0}+\beta_{1} P A R T(A C)_{i r t}+\beta_{2} P A R T(V O C)_{i r t} \\
& +\beta_{3} A G E_{i r t}+\beta_{4} A G E_{\text {irt }}^{2}+\varepsilon_{\text {irt }}
\end{aligned}
$$

where the leavers constitute the base category and $\varepsilon_{\text {irt }}$ is a random disturbance term. We also repeat this procedure for males and females separately. The estimated rates of return are plotted in the south-west quadrant of Figure 4. Although the trend is generally upward, returns fluctuate from year to year, at least in part due to sampling variation.

\section{Cohort Size}

Plotted in the south-east quadrant of Figure 4 is an estimate of the maintained school population over time, our measure of cohort size. Cohort size appears to have fallen sharply after 1987 but started to increase again after 1993.

\section{Regional Variation}

Finally, to get a flavour of the regional variation in these data, Table 3 lists variable means by region calculated over the whole of the sample period 19761996. As the Table shows, there is a large North-South participation divide amounting to 14 percentage points. ${ }^{11}$ As might be expected, exam achievement is highest in those regions with the highest participation rate. The returns to participation show no obvious pattern across regions, but the North-South difference in unemployment is marked. The North-South divide is also apparent with respect to household income.

${ }^{11}$ When making 'North-South' comparisons, we will be referring to the South-East. 


\section{Results}

In this section we present our empirical results. We consider first our panel data models. These include the basic model, as well as models that include region-specific trends and 'reduced-form' models that do not condition on exam achievement. We then allow for the possibility that expectations are based on national level variables and attempt to explain the estimated year dummy variables. Finally, we decompose participation changes over the sample period, focussing on three subperiods of particular interest.

\section{Basic Models, Region-Specific Trends and 'Reduced Form' Models}

For boys, column (1) of Table 4 presents estimates of the basic model (3'). The total number of observations (136) consists of eight regions for 17 years. We lose three years of data (1976-1978) because our first observations from the LFS data are from 1979, and we lose a further year of data (1979) because we instrument those variables subject to sampling error (income and both returns and unemployment by education) using their lagged values.

The most interesting findings are large positive coefficient on the proportion of boys with high levels of exam achievement, the large positive coefficient on youth unemployment and the negative coefficient on cohort size. Based on 1996 sample means, these estimates produce elasticities of roughly $0.5,0.2$ and -0.05 respectively. ${ }^{12}$ All three are very large, but that associated with youth unemployment especially so. To put this in context, we can compute an unemployment elasticity comparable to those discussed in relation to the work of Whitfield and Wilson (1991) and McVicar and Rice (2001). Using the same 1985 sample mean values, we find the unemployment elasticity to be more than three times greater than that estimated by Whitfield and Wilson (1991) and McVicar and Rice (2001). ${ }^{13}$ This suggests that for boys, unemployment effects may be much greater than those previously estimated. ${ }^{14}$

Turning to unemployment and returns by education level, we obtain a mixed pattern of results. Unemployment amongst school-leavers exerts a negative

\footnotetext{
${ }^{12}$ Sample means in 1996 are 68.47 (participation), 36.9 (exam achievement), 17 (youth unemployment) and 66.53 (cohort size, in thousands). Hence the elasticity of participation with respect to exam achievement is $\frac{0.961 * 36.9}{68.47}=0.518$.

${ }^{13}$ Whitfield and Wilson (1991) report (endnote 3 ) that participation amongst boys was $44 \%$ in $1985 / 1986$. Using the 1985 value of youth unemployment from our data (22\%) gives an elasticity of $\frac{0.683 * 22}{44}=0.34$. Recall that the unemployment elasticities associated with the estimates of Whitfield and Wilson (1991) and McVicar and Rice (2001) were 0.1 and 0.08 respectively.

${ }^{14}$ To check the effects of our losing three years of data because of the inclusion of variables generated using the LFS, we re-estimate columns (1) and (4) without the LFS variables. Using the same data as used to generate Table 4, we get estimates (standard errors) on the youth unemployment variables (with and without the inclusion of regional trends) of $0.615(0.091)$ and $0.414(0.105)$. Re-estimating the same equations using the extra three years of available data gives equivalent estimates of $0.376(0.065)$ and $0.411(0.074)$. Hence we find lower youth unemployment effects when we estimate the basic model but not when we augment it to include region-specific trends.
} 
effect on participation, whilst we would expect the opposite. Similarly, unemployment amongst those the participated in academic FE takes a positive rather than a negative sign. None of these estimates are statistically significant however, and as seen from columns (2) and (3) of Table 4, they depend heavily on the way in which these variables are included in the model. This instability could be due to a number of factors. Regarding income, it may be that the aggregate nature of the data obscures true non-linear income effects. It is certainly plausible to imagine that income effects operate only in certain parts of the household income distribution. Regarding unemployment and returns by education level, it may be that our measures of these variables do not accurately reflect the way in which expectations regarding the value of FE participation are formed. We return to this issue below. Notice that our other estimates are not dramatically affected by changes in the way in which these variables are specified. The coefficient on exam achievement increases from 0.96 to 1.06 , the youth unemployment coefficient varies between 0.5 and 0.7 , and the cohort size coefficient falls from -0.066 to -0.032 .

We argued above that region-specific trends need to be included if some of the variables omitted from our model change differentially between regions over time. Column (4) of Table 4 presents the results obtained when equation ( 3 ') is augmented to include region-specific trends. The most dramatic effect is on the exam achievement and income coefficients. Whilst the former is still positive and significant, it is reduced in magnitude by one-half; the latter switches sign and is now negative. These results suggest that when region-specific trends are not included in the model, exam achievement and income may be capturing the effects of omitted variables that change differentially between regions over time. The inclusion of region-specific trends also causes the coefficient estimates associated with youth unemployment and cohort size to fall in magnitude, although both remain important. For instance, given the unemployment coefficient estimate reported in column (4), the comparable unemployment elasticity is still more than twice as large as those estimated by Whitfield and Wilson (1991) and McVicar and Rice (2001).

Also worth discussing are the estimated region dummies and region-specific trend terms. ${ }^{15}$ When region-specific trends are omitted from the model, the difference between the estimated North and South regional dummy variables is 29.5 percentage points. Since this is double the raw North-South participation gap (14 percentage points), it is a startling result. Yet it is easily explained in terms of the very large unemployment effects that we have found. In other words, had unemployment not been considerably higher in the North, the participation gap would have been even larger than the raw differential suggests. When region-specific trends are included, the difference between the regional dummy variables is essentially zero (although very imprecisely estimated), whilst the estimated regional trends suggest that everything else constant, compared to the North, participation in the South increased by an extra 0.3 percentage points

\footnotetext{
${ }^{15}$ The estimated year dummies will be considered when we decompose participation changes over time.
} 
per year.

Finally, we address the possible endogeneity of exam achievement by estimating 'reduced form' models in which measures of exam achievement are omitted from the model. As shown in columns (5) and (6) of Table 4, the resulting estimates - which can be interpreted as the 'full' effects of these variables on participation - are little different from those obtained when exam achievement measures are included. This says simply that none of these variables can explain the observed variation in exam achievement.

We estimate exactly the same series of models for girls, and the results are presented in Table 5. To avoid repetition, we focus on differences between these results and those for boys discussed above. Looking first at the estimates reported in column (1), the most obvious differences relate to the coefficients on income (now negative but still statistically insignificant) and youth unemployment (very much reduced, with an elasticity of 0.04 ). ${ }^{16}$ The finding of smaller unemployment effects for girls is consistent with McVicar and Rice (2001) and some of the microeconometric literature (Rice (1999)). The finding of lower income effects is not, since these are usually estimated to be larger for girls. Like in the case for boys however, a glance across columns (1), (2) and (3) suggests that whilst income effects (and the effects of unemployment by education and returns) are highly dependent on the manner in which these variables are specified, but nearly always statistically insignificant. As stressed in relation to boys, it may be that our measure of income cannot capture true income effects, and that our measures of returns and unemployment by education do not accurately reflect expectations of the economic value of $\mathrm{FE}$ participation.

The introduction of the region-specific trends into the basic model for girls throws up some very interesting results (presented in column (4)). First, in contrast to the case for boys, the introduction of region-specific trends strengthens the effect of exam achievement. That exam achievement is more important for girls than boys is consistent with the microeconomertic literature. Most dramatically, the estimated cohort size coefficient increases almost threefold. That these estimates are so large may reflect the high concentration of girls in certain FE courses. ${ }^{17}$ That these effects are estimated to be so much lower when regional trends are not included presumably reflects the existence of omitted variables that both increase regional cohort size (via migration for example) and increase participation. In that case, a model that excludes region-specific

\footnotetext{
${ }^{16}$ Although unemployment rates amongst young women may more accurately reflect the labour market opportunities facing girls, youth unemployment amongst young women may be more severely affected by patterns of inactivity amongst girls. Although these effects should be picked up by the region and year dummy variables, it may that unemployment amongst young men is a more accurate reflection of the state of the youth labour market facing both boys and girls. Indeed, when we use this measure of unemployment in the equation for girls, the coefficient estimate (standard error) is 0.273 (0.0982), which implies an elasticity of 0.07 . When we include regional trends however, the estimates are very similar. Since this might suggest that the region-specific trends are picking up any changes in inactivity levels, we continue to focus on unemployment amongst young women.

${ }^{17}$ These are most likely to be vocational courses in female-dominated occupations. The Royal Society of Arts (RSA) courses are the most obvious examples.
} 
trends will under-estimate the absolute magnitude of the (negative) cohort size effect. Finally, as found for boys, estimates are not greatly affected by the decision to condition on exam achievement.

\section{Regional versus National Factors in Expectations Formation}

The estimates presented in Tables 4 and 5 are, perhaps, least satisfactory with respect to those variables thought to be capturing the long-run economic value of $\mathrm{FE}$ participation. As argued above however, there are reasons for thinking that these ought also to be measured at the national level. To that end, we use the estimated year dummy variables as the dependent variables in a series of time series regressions that include the national returns to FE participation, and the national levels of unemployment by education. We consider both the year dummy variable estimates taken from the basic model (column (1) in Tables 4 and 5) and those taken from the basic model augmented to include regional trends (column (4) in Tables 4 and 5). We also estimate specifications in which three-year moving averages of returns and unemployment are considered, in addition to those in which only the levels of these variables are used.

Beginning with column (1), we see that for boys, the returns to participating in academic FE courses have the expected positive effect on participation, whilst the returns to participating in vocational $\mathrm{FE}$ have a negative, although statistically insignificant, effect. Turning to unemployment by education, the puzzle here is that unemployment amongst leavers exerts a negative effect on partipation, whilst unemployment amonst those partcipating in vocational and academic FE exerts a positive effect on participation. Although these results are similar for girls, when we turn to three-year moving averages (column (2)), we find that the counter-intuitive effect of unemployment amongst those that participated in the academic sector is reversed, whilst the effects of returns to participation in academic FE are strengthened (the elasticity is now slightly above unity). ${ }^{18}$ For girls, we find the opposite: the counter-intuitive unemployment effects are strengthened whilst the effect of academic returns is now negative. Since we find similar results when we look at the estimated year dummies that control for regional trends, we conclude that whilst we can give a sensible economic interpretation to the estimated year dummy variables for boys, those estimated for girls are far harder to explain.

\section{Decomposing Trends in Participation}

To get a feel for the magnitude of the various effects that we have estimated, and to tell a story regarding the change in participation over time, Table 7 presents a decomposition of the changes in predicted participation across three in-sample periods and an out-of-sample period. Looking at column (1) in the top panel of Tabe 7 , we see that the actual change in participation for boys was

\footnotetext{
${ }^{18}$ Since the dependent variable is measured in percenatge point units, the elasticity of participation amongst boys with respect to the national return to participating in academic FE amonsgt boys is $\frac{212.87 * 0.38}{68.7}=1.177$.
} 
3.409 percentage points. The predicted change based on estimates obtained from column (1) of Table 4 was 3.962 percentage points, which can be decomposed into the effects of changes in all of the independent variables. Notable amongst these is the large positive effect (2.327) coming from an increase in the proportion gaining high levels of exam achievement and the even larger negative effect $(-2.647)$ operating via a decrease in youth unemployment. Increased income and reduced cohort size have small effects, and there is a large component associated with the estimated year dummy variables (4.415), which we have argued can be interpreted as reflecting changes to the national rate of return to academic participation and the level of unemployment amongst those that have participated in academic FE. Looking at the bottom panel of the Table, we see that for girls, more of the (negative) overall change is accounted for by cohort size and less by youth unemployment. Looking down column (2), we see that for both boys and girls, the combination of year dummies and a (population) weighted average of regional trends explains a large part of the changes, although unemployment is still important for boys, and cohort size plays a large role for girls.

Turning to columns (3) and (4), we focus on the period of very rapid participation growth, 1988-1993. In column (3), we see that for boys, the actual increase was an enormous 22.301 percentage points. Of the 22.301 percentage points predicted by our model, the bulk operates via improved exam achievements (11.588), increased unemployment (4.529) and increased cohort size (1.223), with the remainder roughly accounted for by the estimated year dummies. For girls, changes in exam achievement provide the main driving force, with less of the predicted change accounted for by unemployment, and more by the estimated year dummies. In column (4), we see that for boys, the effect of introducing the region-specific trends is to reduce the increase that can be attributed to a change in exam results. For girls, the effect is to increase the proportion that can be attributed to both exam results and reductions in cohort size.

In columns (5) and (6) we examine the period over which participation rates failed to increase. For boys, column (5) suggests that this was the result of increases in unemployment cancelling out improvements in exam achievement. For girls, none of the explanatory variables can explain why participation did not increase, and so the estimated year dummy variables pick up the participation undershoot. When we examine the model augmented to include the regionspecific trends, we get similar results for boys, with increased cohort size now exerting a stronger downward effect on participation for girls.

Finally, columns (7) and (8) examine participation changes out of sample, which have been essentially flat. ${ }^{19}$ For boys, we see from column (7) that the effects of falling youth unemployment are more than cancelling out the effects of improved exam achievement, whilst for girls, changes in youth unemployment still cannot explain the absence of a participation increase over the period. Ex-

\footnotetext{
${ }^{19}$ According to the latest estimates (Statistical Bulletin 14/2001, Table 3), participation increased by less than one percentage point between 1996 and 2001.
} 
amining predictions based on the model including regional trends, and assuming that these trends continued out of sample, the change in unemployment cancels out most but not all of the predicted increase in participation for boys, whilst reduced unemployment and increased cohort size cancel out only some of the predicted participation increase for girls. Overall therefore, our estimated models can to a large extent account for observed changes in participation amongst boys. For girls, the unexplained component is much larger.

\section{Additional Evidence}

Whilst the weight that our story places on exam achievement is not new, our results suggest that unemployment plays the key supporting role, at least for boys. We now examine two additional pieces of evidence in support of this finding.

\section{Evidence from Scotland}

Perhaps the most interesting period of our sample are the years from 1987 (the year before the first GCSE exams were taken) to 1993 (the year in which participation peaked). Over these five years, FE participation in England grew by more than 24 percentage points, roughly $40 \%$ of the total post-war increase. Our explanation of this increase rests on the unprecedented increase in the proportion of students with greater than five higher grade GCSEs (13.5 percentage points) coupled with the large increase in youth unemployment that occurred over this period. Overall, youth unemployment increased by six percentage points, although it increased by 13 percentage points between 1989 and 1992 . Since these twin phenomenon of rapidly rising exam achievement and rapidly rising youth unemployment occurred at the same time, there may linger a suspicion that our unemployment results are somehow confusing the two, or picking up something else going on over this period, such as the rapid growth in higher education (recall that McVicar and Rice (2001) gave this the key supporting role).

As a check on the validity of our unemployment explanation, a comparison of FE participation trends in England and Scotland over this period can be thought of a a rough but useful natural experiment. This is useful because the two countries differed drastically in the changes in unemployment experienced over this period. Unlike the case of England, in Scotland, where the 1980s boom and subsequent recession occurred later and were not so marked, youth unemployment fell slightly over the 1987-1992 period as a whole, and grew by only three percentage points between 1989 and 1992. ${ }^{20}$ As such, were everything else between the two countries constant, our story would imply that participation should have increased substantially over this period (by virtue of the improved

\footnotetext{
${ }^{20}$ Scottish youth unemployment defined analagously to English youth unemployment. Numerators derived from various issues of Regional Trends; denominators from the Scottish Executive.
} 
exam achievement) but by less than the increase in England (because of the absence of a significant unemployment increase). To check that other things can be thought of as constant between the two countries, note that Scotland experienced a similarly large increase in exam achievement between 1987 and 1993, and an even larger increase in HE participation. ${ }^{21}$ We have no reason to suppose that changes in socio-economic factors (captured by the year dummy variables in our regional-level analysis) differed drastically between the two countries over such a short period of time.

Turning to the participation data, we find exactly what we would expect. From a relatively stable base in the mid 1980s, participation in Scotland grew by 14.3 percentage points over the period $1987-1993$, from $59 \%$ to $73.3 \%$. This is a substantial rise, but is almost ten percentage points smaller than the 24 percentage point increase seen in England. ${ }^{22}$

\section{Evidence from College Principals and Young People}

As a final check on the importance of unemployment to the FE participation decision, we consider the views of students and college principals. Thomas (2000) reports the results of a survey of young people leaving school in 1977. Although the survey is somewhat dated, it is interesting to note that out of nine possible reponses for deciding not to participate, the propositions with which the most non-participants strongly agreed were 'chance of a good job' and 'wants own money'. ${ }^{23}$ Although unemployment as a reason to participate (not an option in the survey) might constitute more direct evidence of an unemployment effect, these responses at least suggest that the state of the local labour market weighs heavily on the minds of non-participants.

Regarding the supply side, Green and Ainley (1995) report the results of a survey of school and college principals/managers drawn from different regions of England and Wales. The survey was designed to analyse, inter alia, current and future trends in participation. Regarding the large participation increases seen in the years leading up to 1994, Green and Ainley (1995) report that "(T)hose interviewed invariably cited jobs as the chief factor driving recent increases in

\footnotetext{
${ }^{21}$ Scottish exam achievement data obtained from various issues of Regional Trends. Although data are not comparable between 1992 and 1993, the proportion of school-leavers with no qualifications fell by 10.8 percentage points between 1987 to 1992 . Scottish HE participation data obtained from the Scottish Executive on the same basis as English data (the 'Age Participation Index' (API)) from 1988. Between 1987 (1988) and 1993, the English (Scottish) API increased by 15.3 (18.7) percentage points, from $17.1 \%(21.4 \%)$ to $32.4 \%(40.1 \%)$.

22 Scottish participation data from the Scottish Executive. To complete the Scottish picture, whilst participation in England peaked in 1993, participation in Scotland rose by a further 5.5 percentage points between 1993 and 1996. Although this is consistent with the smaller drop in Scottish youth unemployment (three rather than five percentage points) and the larger rise in Scottish exam achievement (five rather than four percentage points), our explanation for the English trends would not seem to capture the whole of this difference in participation growth.

${ }^{23}$ Of a sample of 1237 non-participants, 579 and 571 strongly agreed with these propositions. The next two most strongly agreed with propositions were 'taking apprenticeship' (459) and 'better chance of finding a job now' (444).
} 
participation, and this applied in each of the regions" (p.12). Regarding the prospects for future growth, they report that " $(\mathrm{O}) \mathrm{n}$ balance, the evidence from the interviews was that there would continue to be increases in participation, but that the rate of increase would begin to slow down, particularly as the economy picks up" (p.14). That both the demand and supply side of the FE market recognise the importance of the local labour market adds further weight to our results.

\section{Conclusions}

We started out by noting that FE participation is widely regarding as the engine driving educational performance in Britain, and that policies to increase participation are very high up the education policy agenda. Yet we also argued that these policies are not accompanied by a convincing analysis of the reasons why participation failed to increase after 1993. On the basis of Figure 2, we speculated that the state of the labour market (as measured by youth unemployment) could be the missing piece of the participation jigsaw and conjectured that the weak correlation between participation and unemployment estimated previously may be due to the limited nature of the time series data used.

To that end, we constructed a new regional panel dataset and showed that youth unemployment did indeed play a very important role in explaining participation trends. However we slice the data, and however we control for omitted variables, we find unemployment effects that are at least twice as large as those previously estimated, and which can broadly explain recent participation trends, at least amongst boys. In addition, we showed that different youth unemployment patterms could potentially account for participation differences between England and Scotland, and we also consdired the views of school-leavers and FE college managers. Both seem to agree on the fundamental importance of the local labour market to participation. Other empirical results confirmed the importance of exam achievement to participation, and highlighted significant positive effects of national returns to participation (for boys) and and large negative effects of cohort size (especially for girls).

How do our results impact on Government policies to increase the participation rate? First, they confirm that policies which will eventually increase exam achievement can be expected to increase participation. Unfortunately however, exam achievement cannot increase forever, and as seen in Figure 2, the rate of increase shows signs of slowing down. Secondly, and more importantly, our results suggest that for a substantial minority of school-leavers, the labour market is more attractive than the classroom. This may be because school-leavers are financially constrained from participating in full-time FE, in which case the Government's EMA policy can be expected to increase participation. Alternatively, it may simply be that these students do not like and are not suited to classroombased study. In that case, Government time and resources currently devoted to increasing participation in full-time FE may be more fruitfully spent improving and expanding the range of work-based training options open to young peo- 
ple. Although the Government has emphasised the importance of work-based training and attempted to improve the system of Modern Apprenticeship at its core, as Steedman (2001) and Fuller and Unwin (2001) spell out in detail, these remains vastly inferior those found in Continental Europe. 


\section{A Data Appendix}

In this Appendix, we describe how three data series were constructed: Participation, Exam Achievement and Youth Unemployment.

\section{A.1 Participation Rates}

FE participation rates are calculated as the sum of participation rates in the Schools sector (which includes School Sixth Forms and Sixth-Form Colleges until 1993) and the Further Education sector (which includes Further Education Colleges, Tertiary Colleges, and Sixth Form Colleges after 1993).

\section{A.1.1 Participation in the Schools Sector}

We define the rate of participation in the Schools sector as the fraction of the maintained school population of school-leaving age continuing in full-time education in maintained schools. ${ }^{24}$ We refer to the rate of participation in a given year (say 1989) as the proportion of the cohort of children whose final compulsory academic year is 1988-1989 (and who finish compulsory education some time between the Easter and summer of 1989) that are recorded in education in the following January (1990). The series is constructed as follows:

\section{6-1979}

These proportions are taken directly from 'Statistics of Education: Schools'. For example, the participation rate for 1978 (taken from 'Statistics of Education

\footnotetext{
${ }^{24}$ The distinction between 'maintained' and 'non-maintained' schools is an important one, since for reasons of data availability, we calculate participation rates and exam achievements for the maintained sector only. Broadly speaking, 'maintained' schools are those operated by (local or central) Government, whilst 'non-maintained' schools are those operating outside of direct Government control. To get a rough idea of the quantitative importance of each sector, note that in 1975 (one year before our first observation), the non-maintained sector constituted $5.17 \%$ of all pupils in secondary schools in England. By the last year in the sample, the figure had increased slightly, to $6.88 \%$. This number comes from Statistics of Education 1996: Schools, Table 3. Figures for independent schools cover both primary and secondary schools, hence we use the proportion in secondary schools taken from the data used to construct the proportion in 1974. Although this may have changed slightly over time, any changes will not alter our benchmark estimate of a non-maintained proportion in the region of $5-7 \%$.

Data permitting, we would prefer to focus on the broader measure, since we are interested in the participation behaviour of all school-leavers. However, as well as being a small group, the excluded category displays much higher participation rates than the group that we focus on. For example, in the first year for which we have data (1976), the participation rate in the schools sector (i.e. the proportion of the maintained school population participating in schools or sixth form colleges but not further education colleges) was $25.7 \%$ in the maintained sector and $68.2 \%$ in the non-maintained sector (See Statistics of Education 197\%: Schools, Table 10(i)). This latter figure is close to the participation rate in both the schools sector and the FE sector for those in the maintained sector at the end of the sample period (in 1996, the figure is $71 \%$ ). Hence not only do school-leavers from the non-maintained sector display very different patterns of participation, but from a policy point of view, if we are interested in increasing participation, then focusing on the maintained sector makes some sense.
} 
1979: Schools') is calculated as:

$$
\operatorname{Part}^{\mathrm{SCHOOL}}(1978)=\frac{\# 16 \text { in Jan } 1979}{\# 15 \text { in Jan } 1978}
$$

and we use the symbol \# to denote 'the number aged'. Here, both the numerator and the denominator refer to those whose birthdays fall between January and December, where this is designed to avoid including those aged 16 in January in their final year of compulsory education.

1980-1991

These proportions are taken directly from 'Statistics of Education: Schools'. They are calculated exactly as above, except that both the numerator and the denominator refer to those aged 15 and 16 at the beginning of the academic year (31 August). Although this introduces a discontinuity into the series, this is not thought to be large. To see this, compare the proportions for the whole of England for 1976-1978 as calculated on the first basis (published in 'Statistics of Education 1976-1979: Schools') and the second basis (published in 'Statistics of Education 1980: Schools'). For example, for 1978, the proportion calculated on the first basis is 24.4, whilst the proportion calculated on the second basis is 24.5.

\section{2-1993}

These proportions are calculated using totals taken from 'Statistics of Education: Schools' volumes. For example, the participation rate for 1992 is calculated as:

$$
\operatorname{Part}^{\mathrm{SCHOOL}}(1992)=\frac{\# 16 \text { in Jan } 1993}{\# 15 \text { in Jan } 1992}
$$

where the numerator is taken from 'Statistics of Education 1993: Schools' and the denominator from 'Statistics of Education 1992: Schools'.

1994

In this year, the numerator is from data supplied by the DES. The denominator is from 'Statistics of Education 1994: Schools'. Since DES data is on a GOR basis, the DES number (numerator) is adjusted. This is done by comparing the number of 16 year olds on the old (SSR) basis and on the new (GOR) basis in 1994 (the only year for which we have overlapping data). Hence:

Part $^{\text {SCHOOL }}(1994)=\frac{\# 16 \text { in } 1995 \text { on GOR basis }}{\# 15 \text { in } 1994 \text { on SSR basis }} * \frac{\# 16 \text { in } 1994 \text { on SSR basis }}{\# 16 \text { in } 1994 \text { on GOR basis }}$

1995-1998

In these years, both numerator and denominator are calculated using data supplied by the DES. Again, since the data are on a GOR basis, they need to 
be adjusted to be consistent with our earlier data. This is done by adjusting the number of 15 year olds and the number of 16 year olds in the manner described above. The adjustment factor attempts to account for different trends across the newly defined regions. For example, the participation rate for 1996 is calculated as:

$$
\operatorname{Part}^{\mathrm{SCHOOL}}(1996)=\frac{\# 16 \text { in } 1997 \text { on GOR basis }}{\# 15 \text { in } 1996 \text { on GOR basis }} * \frac{\# 16 \text { in } 1994 \text { on SSR basis }}{\frac{\# 15 \text { in } 1994 \text { on GOR basis }}{\# 15 \text { in } 1994 \text { on GOR basis basis }}}
$$

\section{A.1.2 Maintained School Population}

In order to calculate some of our other series, we will need a series for the maintained school population (MSP) of school-leaving age. This is calculated as follows:

\section{0-1994}

We take this from 'Statistics of Education: Schools', volumes 1991-1994.

1995-1996

For 1995-1996, we use data supplied by the DES. Although this on a GOR basis, we adjust using data we have for 1994 on both bases (GOR and SSR).

1977-1991

We take this from 'Statistics of Education: School-Leavers Survey', volumes 1979-1990. Since these figures are collected differently we adjust this series to make it consistent with the 1990-1994 data using data we have on both bases for 1990 .

1976

We do not have data on the MSP for 1976, hence we use data for 1977 .

\section{A.1.3 Participation in the Further Education Sector}

We define the proportion participating in the FE sector as the fraction of the maintained school population of school-leaving age continuing in full-time education in the FE sector measured in the November of the same year. This again raises a conceptual issue, in that some of those school-leavers observed in further education may have come from non-maintained schools. However, Payne (1996) shows that only one in five of the students from non-maintained schools moved to an FE college, the vast majority continuing in school. Hence we ignore this problem in analysing the numerators (numbers in FE).

1976-1979

Relevant proportions taken from 'Regional Trends' where the denominator is the 'maintained school population of school-leaving age'. 
1981-1982

In these years, the published statistics use as the denominator the 'population aged 16', hence we calculate the numerators by multiplying by the 'population aged 16' figure presented in 'Regional Trends' and use our series for the 'maintained school population of school-leaving age' to derive the correct proportions. Again we ignore the fact that the definition of a 16 year old changed between 1978 and 1979. Hence:

$$
\operatorname{Part}^{\mathrm{FE}}(1981)=\frac{\operatorname{Part}^{\mathrm{FE}(\mathrm{RT}) *} \text { Population Aged } 16(1981)}{\text { Maintained School Population (1981) }}
$$

\section{$1984-1986$}

See above.

$1988-1993$

In these years, the numerators are published in 'Regional Trends', and so we use these and our estimates of the maintained school population of schoolleaving age. Hence:

$$
\operatorname{Part}^{\mathrm{FE}}(1988)=\frac{\# \text { in FE (1988) }}{\text { Maintained School Population (1988) }}
$$

1980, 1983, 1987

There are no data for these years in 'Regional Trends'. Hence the proportions are a weighted average of those in the year before and the year after, where the weights are calculated using the number of 16-18 year olds in further education taken from 'Statistics of Education: Further Education'. For example:

$$
\begin{aligned}
\operatorname{Part}^{\mathrm{FE}}(1987)= & \operatorname{Part}^{\mathrm{FE}}(1986) * \frac{(\# \mathrm{FE} \text { in 1988)-(\# FE 1987) }}{(\# \mathrm{FE} \text { in 1988)-(\# FE in 1986) }} \\
& +\operatorname{Part}^{\mathrm{FE}}(1988) * \frac{(\# \mathrm{FE} \text { in } 1987)-(\# \mathrm{FE} \text { in } 1986)}{(\# \mathrm{FE} \text { in 1988) }-(\# \mathrm{FE} \text { in 1986) }}
\end{aligned}
$$

1994-1996

For these years, we have data on the proportions of interest from 'Regional Trends' 1997, 1998 and 1999. However, these are based on GORs and the proportions are expressed as a percentage of the total population rather than the maintained school population. Hence to make them consistent with our earlier series, we make two adjustments: (a) we use information on the numbers of students in FE by region on both region definitions (SSR and GOR) for 1993/94 (where the data comes from 'Regional Trends' 1997) and (b) we use estimates of the total population in 1993 derived from 'Regional Trends' 1996 
to adjust for the fact that the denominators change from the MSP to the total population. For example, for 1995 we have:

$$
\operatorname{Part}^{\mathrm{FE}}(1995)=\mathrm{Part}^{\mathrm{FE}(\mathrm{GOR})}(1995) * \frac{\# \mathrm{FE} \text { in } 1994 \mathrm{SSR}}{\# \mathrm{FE} \text { in } 1994 \mathrm{GOR}} * \frac{\text { total popn }(1993)}{\mathrm{MSP}(1993)}
$$

\section{A.1.4 Disaggregation by Sex}

Regarding participation in the schools sector, data in each of the sources described is disaggregated for boys and girls. Unfortunately, for participation in the FE sector, we do not have separate data for boys and girls on the figures of interest. We do however, have data on the total numbers of males and females in further education (which is not the same, since we are interested in only 16 year olds). We now describe how we use this data to disaggregate by sex.

\section{Pre-1988}

To split the proportion of 16 year olds in FE into seperate proportions for boys and girls, we use data from 'Statistics of Education: Further Education' on the proportions of boys and girls aged 16-18 studying in the FE sector. This entails two assumptions:

1. That the proportions of boys and girls in the MSP are equal

2. That the proportions of boys and girls in the 16-18 totals mirror the proportions in the age 16 totals that we are interested in.

To assess the validity of the second assumption, we can use national-level data from 'Statistics of Education 1987: Further Education'. For 1987, the ratio of boys to girls in the age 16 totals for full-time study is 0.75 . In the aged 16-18 groups that we actually use, the proportion is $0.76 .^{25}$ Hence it would appear that the adjustment is reliable. Taking 1984 as an example, we calculate the proportion of girls participating in the FE sector as:

$$
\operatorname{Part}^{\mathrm{FE}(\mathrm{GIRLS})}(1984)=\frac{2^{*} \operatorname{Part}^{\mathrm{FE}}(1984)}{1+\operatorname{ratio}^{\mathrm{bg}}(1984)}
$$

where:

$$
\text { ratio }^{\text {bg }}(1984)=\frac{\# \text { boys }}{\# \text { girls }}
$$

and the proportion of boys as:

$$
\operatorname{Part}^{\mathrm{FE}(\mathrm{BOYS})}(1984)=2^{*} \operatorname{Part}^{\mathrm{FE}}(1984)-\operatorname{Part}^{\mathrm{FE}(\mathrm{GIRLS})}(1984)
$$

\footnotetext{
${ }^{25}$ See 'Statistics of Education 1987: Further Education', Table F3.
} 


\section{$1988-1996$}

From 1988 we perform the same calculations using a slightly different series published in 'Regional Trends'. To make sure this is consistent with our earlier calculations we adjust this series using overlapping data for the year 1987. Since we do not have any data for 1994 we take a simple average of our calculations for 1993 and 1995. Similarly, we do not have data for 1996 and so we use the proportions calculated for 1996.

\section{A.2 Exam Achievement}

We define four mutually exclusive categories of exam achievement - five or more higher grade O levels/CSEs/GCSEs; between one and four higher grade O levels/CSEs/GCSEs; at least one pass at another grade; no graded passes. In what follows, we describe how they are calculated.

\section{A.2.1 Post-1992}

\section{$1995-1996$}

These proportions are taken from 'Statistics of Education: Exam Achievements' and refer to maintained schools only

1992-1994

Since the published proportions are not split by sex, we use data from the DES that is split by sex. MSP totals are used to construct weighted averages for the 'South East' from the data given for 'Greater London' and 'Other South East'

\section{A.2.2 Pre-1992}

\section{9-1991}

These are calculated from 'Statistics of Education: School-Leavers'. Three issues with these data are:

1. The Tables only provide us with data for school-leavers

2. The Tables refer to both maintained and non-maintained schools

3. The Tables only provide data on the exam achievements of all school leavers without A level passes (which includes GCSE resits and/or A level failures 
For 1989, 1990 and 1991, we solve this problem by computing exam achievements as (using $>5$ GCSEs as an example):

$$
\mathrm{GCSE}^{5}=\mathrm{Part}^{\mathrm{SCHOOL}} * \operatorname{adj}_{1}+\left(1-\mathrm{Part}^{\mathrm{SCHOOL}}\right) * \mathrm{GCSE}^{5}(\text { Leave })
$$

where:

$$
\operatorname{adj}_{1}=\operatorname{Pr} \text { opn }(\text { STAY }) \& G C S E E^{5}
$$

and this data on exam achivements by intended destination comes from 'Statistical Bulletins' 1/91 (1989), 15/92 (1990) and 22/92 (1991). Since these Bulletins do not provide this data by region, we make the same adjustment for each region. Before 1989, we use the adjustment factors found for 1989.

\section{A.2.3 1991 and 1992}

Since the figures before 1992 refer to all schools, whereas the figures for 1992 onwards are calculated for maintained schools only, we use data for 1992 on both bases to adjust the earlier series. This data is found in 'Regional Trends' 1994. For example, for 1991 we have:

$$
\operatorname{GCSE}^{5}(1991)=\operatorname{GCSE}^{5}(1991)^{+*} \frac{\operatorname{GCSE}^{5}(1992)^{\mathrm{NEW}}}{\operatorname{GCSE}^{5}(1992)^{\mathrm{OLD}}}
$$

where the superscript ' + ' is used to denote the series being adjusted.

\section{A.3 Youth Unemployment Rates}

We calculate an unemployment rate as the ratio of total unemployed to relevant population.

\section{A.3.1 Unemployment Levels}

After 1979

From 1980-1996, we calculate the numbers unemployed aged 18-19. In each of these years, 'Regional Trends' breaks down the total claimant count into the proportions in various age groups, including this one. We therefore use this information to calculate our totals.

\section{Before 1979}

Before 1979, we have data only for men, and the 18-19 group becomes the under-20 group. We use information from 1979 on the ratio of male to female claimants in each group and the proportions of the under-20 claimants aged 18-19. 


\section{A.3.2 Relevant Population}

After 1990

After 1990, we have data on the population of 18-19 year olds in each region supplied by the Office for National Statistics (ONS).

1980-1990

Before 1990, we do not have data on the population aged 18-19. To generate this figure, we use the total school-leaving population two and three years ago (from 'Regional Trends'). We do not have this information by sex, hence we impose a 50-50 male/female split.

\section{6-1979}

Before 1980, we do not have data on the total school-leaving population, hence we use data on the maintained school-leaving population instead, adjusting this series using data for both measures in 1980. Again, we do not have this information by sex, hence we impose a 50-50 male/female split. 


\section{References}

Andrews, M., And S. Bradley (1997): "Modelling the Transition from School and the Demand for Training in the United Kingdom," Economica, 64, 387-413.

Ashworth, K., J. Hardman, W. C. Lui, S. Maguire, S. Middleton, L. Dearden, C. Emmerson, C. Frayne, A. Goodman, H. Ichimura, And C. Meghir (2001): "Educational Maintenance Allowance: the first year, a quantitative evaluation," Department of Education and Skills Research Brief No. 257, March 2001.

Becker, G. S. (1964): Human Capital: A Theoretical Analysis with Special Reference to Education. Columbia University Press, New York.

(1967): Human Capital and the Personal Distribution of Income. University of Michigan Press, Ann Arbor.

Bell, B., S. Nickell, And G. Quintini (2000): "Wage Equations, Wage Curves and All That," Centre for Economic Performance (CEP) Discussion Paper No. 471.

Ben-Porath, Y. (1967): "The Production of Human Capital and the LifeCycle of Earnings," Journal of Political Economy, 75, 352-356.

Betts, J. R., and L. L. McFarland (1995): "The Impact of Labor Conditions on Community College Enrollments," Journal of Human Resources, 30(4), 741-765.

Cameron, S., and J. Heckman (1998): "Life Cycle Schooling and Educational Selectivity: Models and Choice," Journal of Political Economy, 106, 262-333.

CARD, D. (1999): "The Causal Effect of Education on Earnings," in Handbook of Labour Economics Volume 3A, ed. by O. Ashenfelter, and D. Card. Elsevier, Amsterdam.

Card, D., and T. Lemieux (2000): "Dropout and Enrolment Trends in the Post-War Period: What Went Wrong in the 1970s?," National Bureau of Economic Research (NBER) Working Paper No. 7658.

Chevalier, A., and G. Lanot (2001): "The Relative Effect of Family Characteristics and Financial Situation on Educational Achievement," Centre for Economic Performance (CEP), LSE, mimeo.

Freeman, R. B. (1986): "Demand for Education," in Handbook of Labour Economics Volume I, ed. by O. Ashenfelter, and R. Layard. Elsevier, Amsterdam.

Fuller, A., And L. Unwin (2001): "From Cordwainers to Customer Service: The Changing Relationship Between Apprentices, Employers and Communities in England," SKOPE Discussion Paper, Oxford and Warwick Universities, ISSN 1466-1535. 
Green, A., and P. Ainley (1995): "Progression and Targets in Post-16 Education and Training," Post-16 Centre Report 11, Institute of Education, London.

KAne, T. J. (1994): "College Entry by Blacks since 1970: The Role of College Costs, Family Background and the Returns to Education," Journal of Political Economy, 102(5), 878-911.

McVicar, D., And P. Rice (2001): "Participation in Full-Time Further Education in England and Wales: An Analysis of Post-War Trends," Oxford Economic Papers, 53, 47-56.

Micklewright, J. (1989): "Choice at Sixteen," Economica, 56, 25-39.

Micklewright, J., M. Pearson, and S. Smith (1990): "Unemployment and Early School Leaving," Economic Journal, 40(100), 163-169.

Moulton, B. (1990): "An Illustration of a Pitfall in Estimating the Effects of Aggregate Variables on Micro Units," Review of Economics and Statistics, $72,334-338$.

Payne, J. (1996): "Routes Beyond Compulsory Schooling," Education Department Research Series Youth Cohort Report 31 (January).

Petrongolo, B., and M. J. San Segundo (2002): "Staying-on at School at 16: the impact of labour market conditions in Spain," Economics of Education Review, 21(4), 353-365.

Pissarides, C. (1981): "Staying-on at School in England and Wales," Economica, 48, 345-363.

(1982): "From School to University: The Demand for Post-Compulsory Education in Britain," Economic Journal, 92, 654-667.

Rice, P. (1987): "The Demand for Post-Compulsory Education in the UK and the Effects of Educational Maintenance Allowances," Economica, 54, 465-475.

(1999): "The Impact of Local Labour Markets on Investment in Further Education: Evidence from the England and Wales Youth Cohort Studies," Journal of Population Economics, 12, 287-312.

Rosen, S. (1977): "Human Capital: A Survey of Empirical Research," in Research in Labor Economics, Vol. 1, ed. by R. Ehrenberg, pp. 3-40. JAI Press, Greenwich, Conn.

SheA, J. (2000): "Does Parent's Money Matter?," Journal of Public Economics, $77,155-184$.

Steedman, H. (2001): "Benchmarking Apprenticeship: UK and Continental Europe Compared," Centre for Economic Performance (CEP) Discussion Paper No. 513. 
Thomas, W. (2000): "The Role of Peer Group in the Staying-On Decision at Sixteen," Working Paper No. 32, University of the West of England, Bristol.

Whitfield, K., and R. Wilson (1991): "Staying on in Full-Time Education: The Educational Participation Rate of 16 Year Olds," Economica, 58, 391404.

WiLlis, R. J. (1986): "Wage Determinants: A Survey and Reinterpretation of Human Capital Earnings Functions," in Handbook of Labor Economics, ed. by O. Ashenfelter, and R. Layard, pp. 525-602. North Holland, Amsterdam. 
Figure 1: Participation in Further Education (\%)

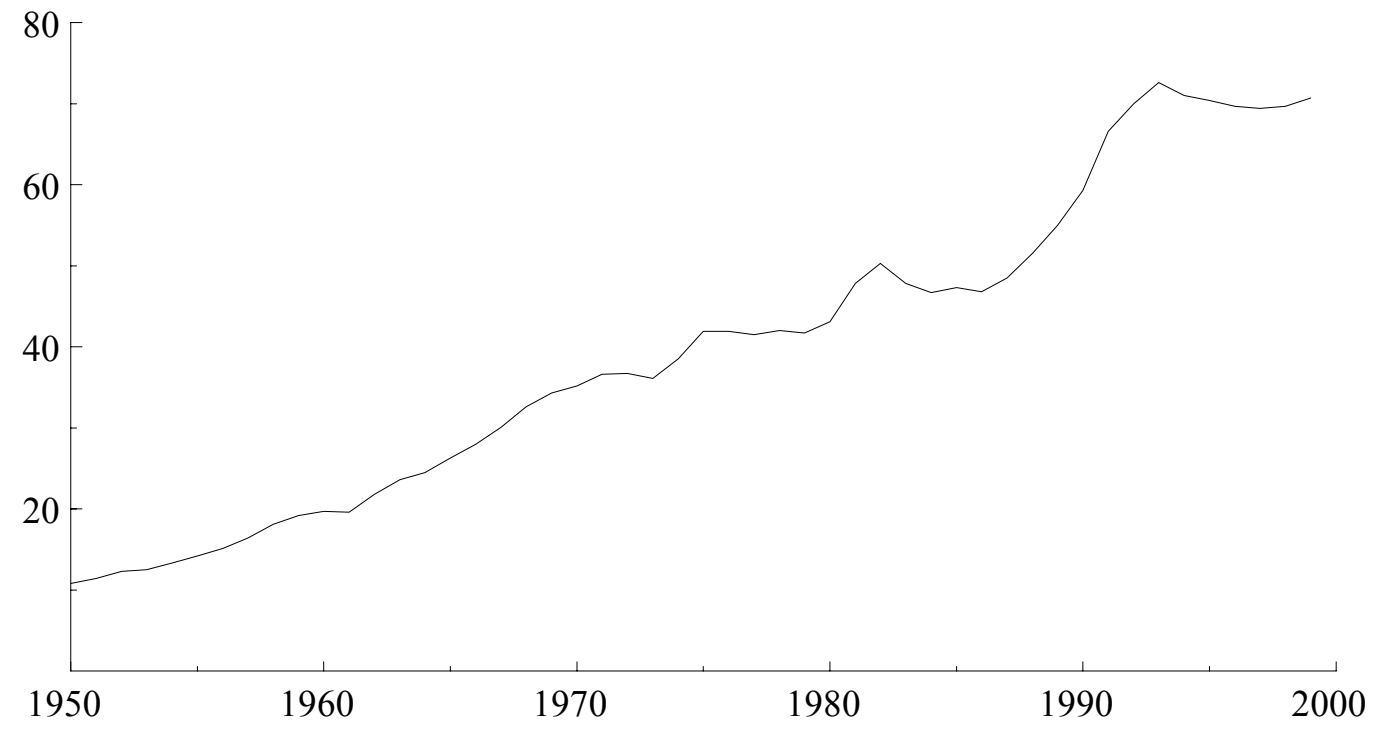

Notes: Data provided by the DfES. These refer to all School pupils (recorded in January) and all FE pupils (recorded in November) as a percentage of the cohort aged 16 in the previous August (or 15 before the raising of the schoolleaving age in 1972).

Figure 2: Participation, Exam Achievement and the Labour Market

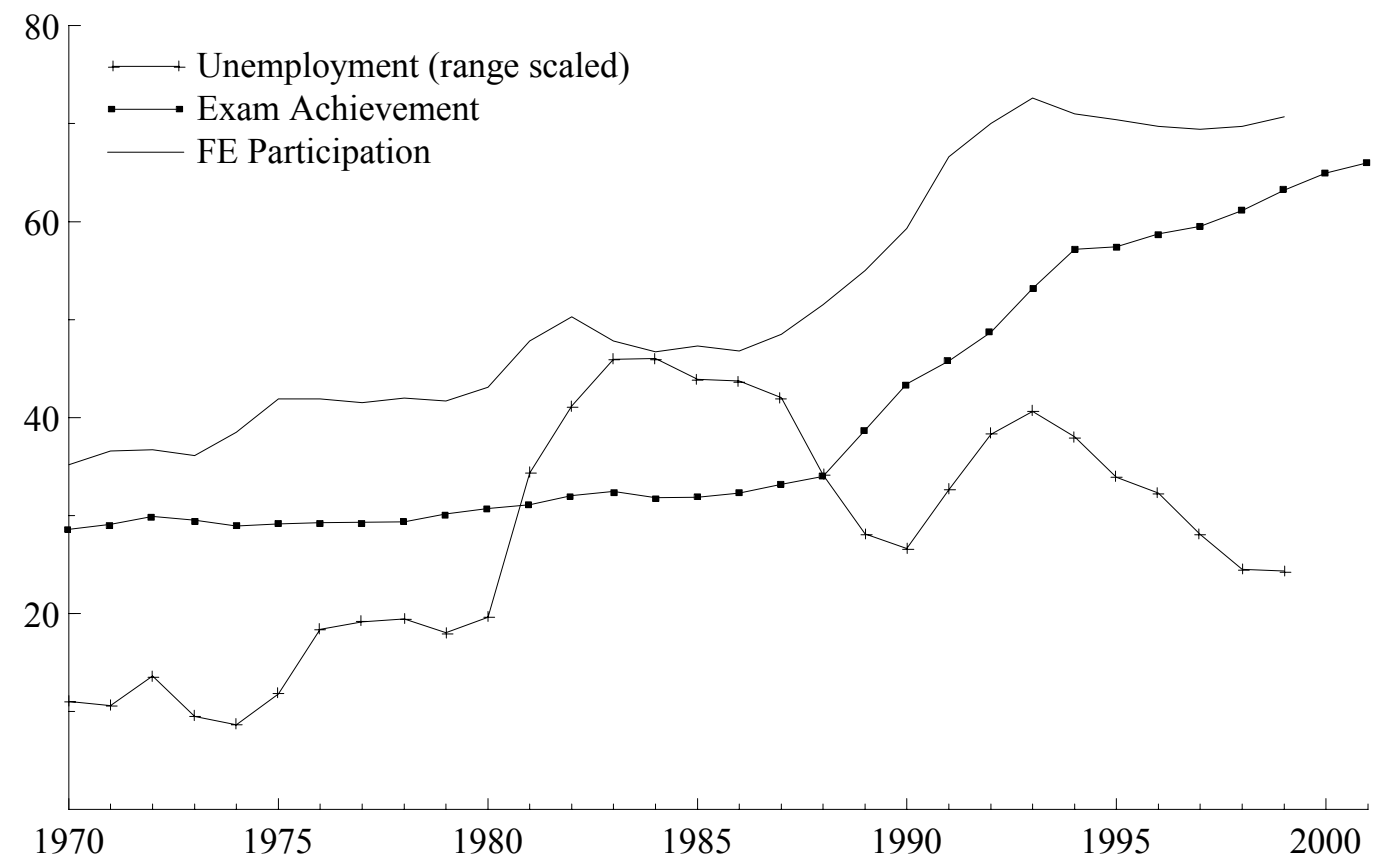

Notes: FE Participation as in Figure 1. Exam Achievement series measures the proportion of school-leavers achieving five or more higher grade GCSE (or O level) passes. Data for 1994-2000 from DfES Statistical Bulletins. Before 1994, data are taken back using a series very kindly provided by Duncan McVicar (see McVicar and Rice (2001) for details. Unemployment based on LFS definition from 1984-1999 and taken back using the estimated claimant count rate. 
Figure 3: Individual-Level Data
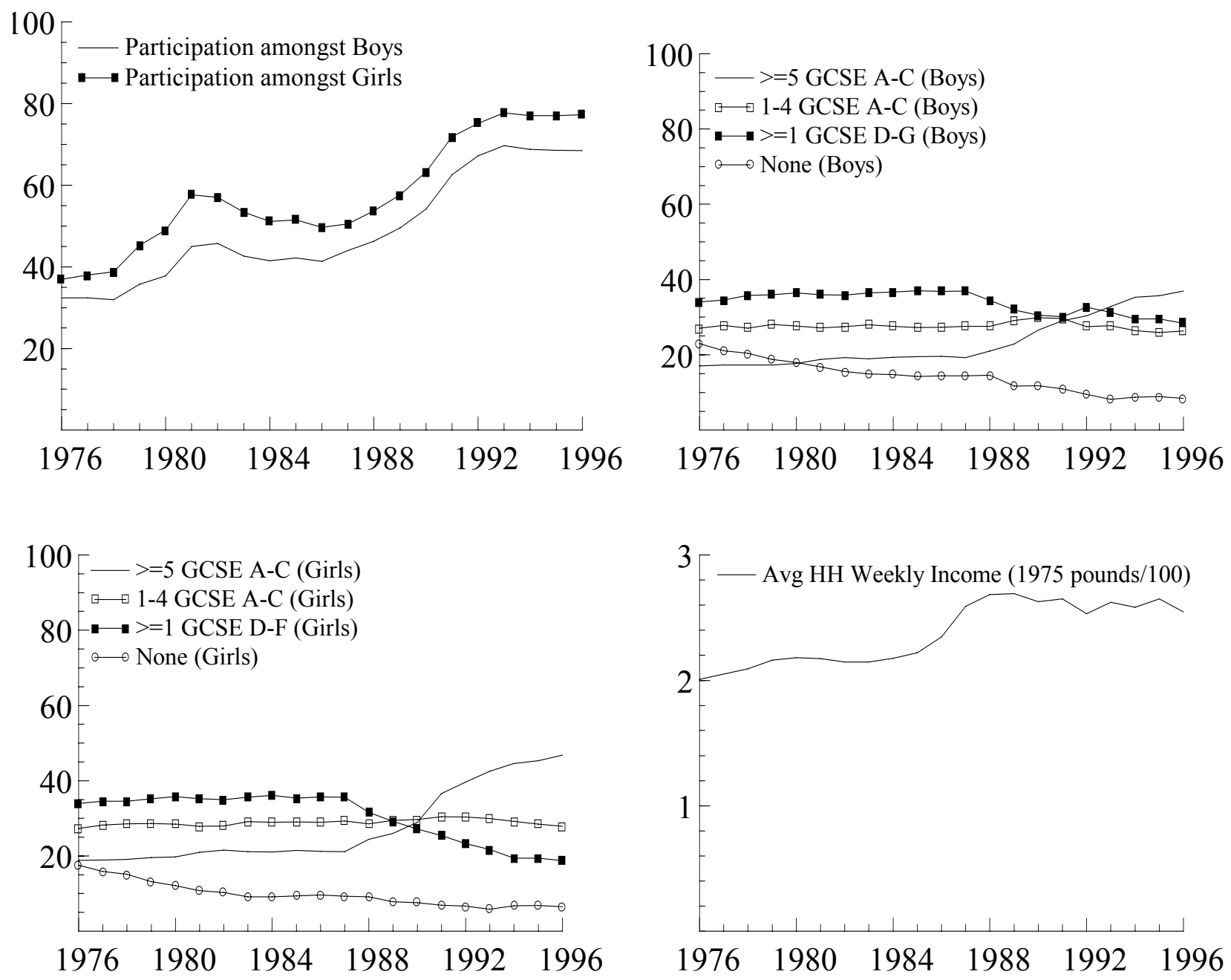
Figure 4: Regional-Level Data
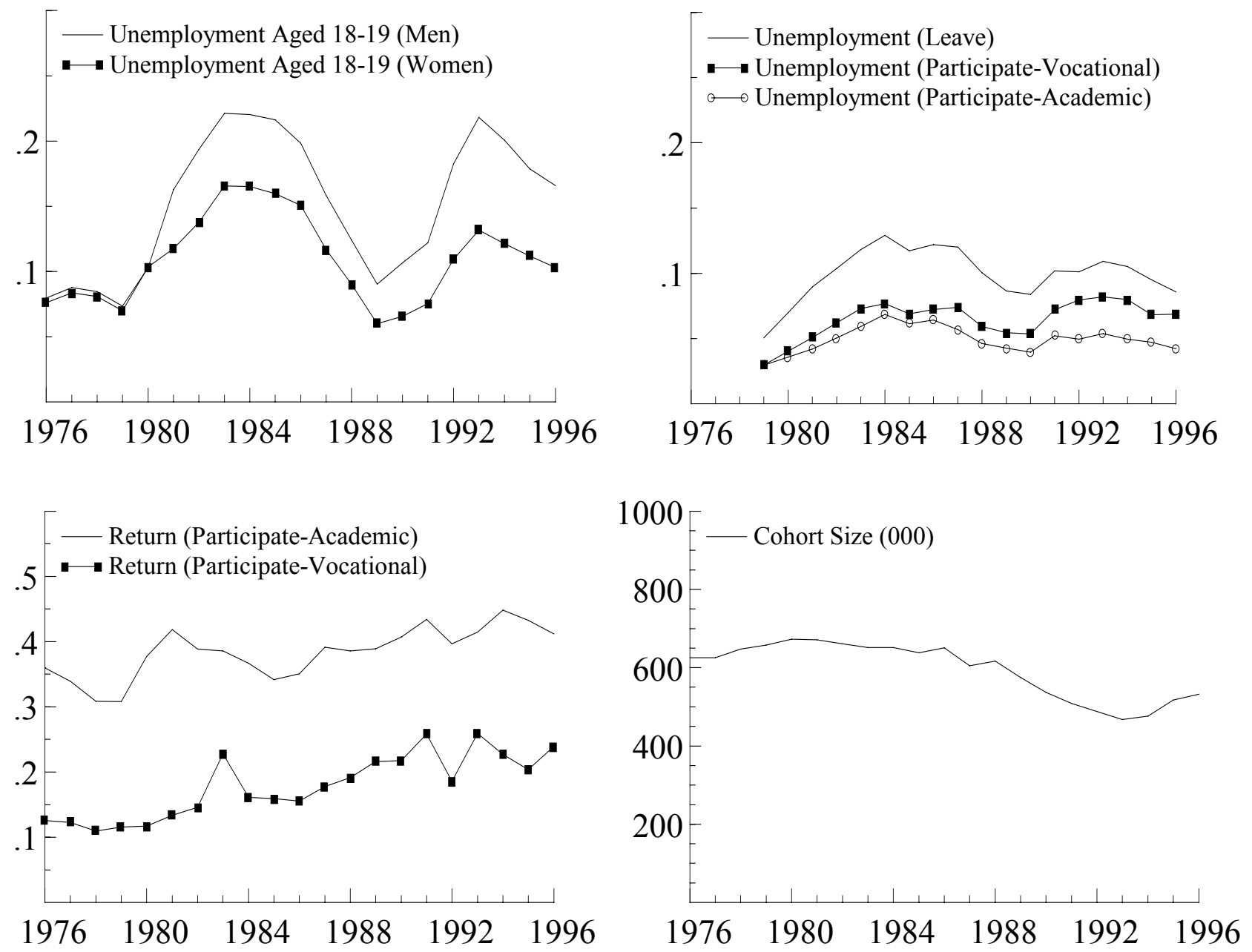
Table 1: Changes in the Participation Environment: 1975-1996

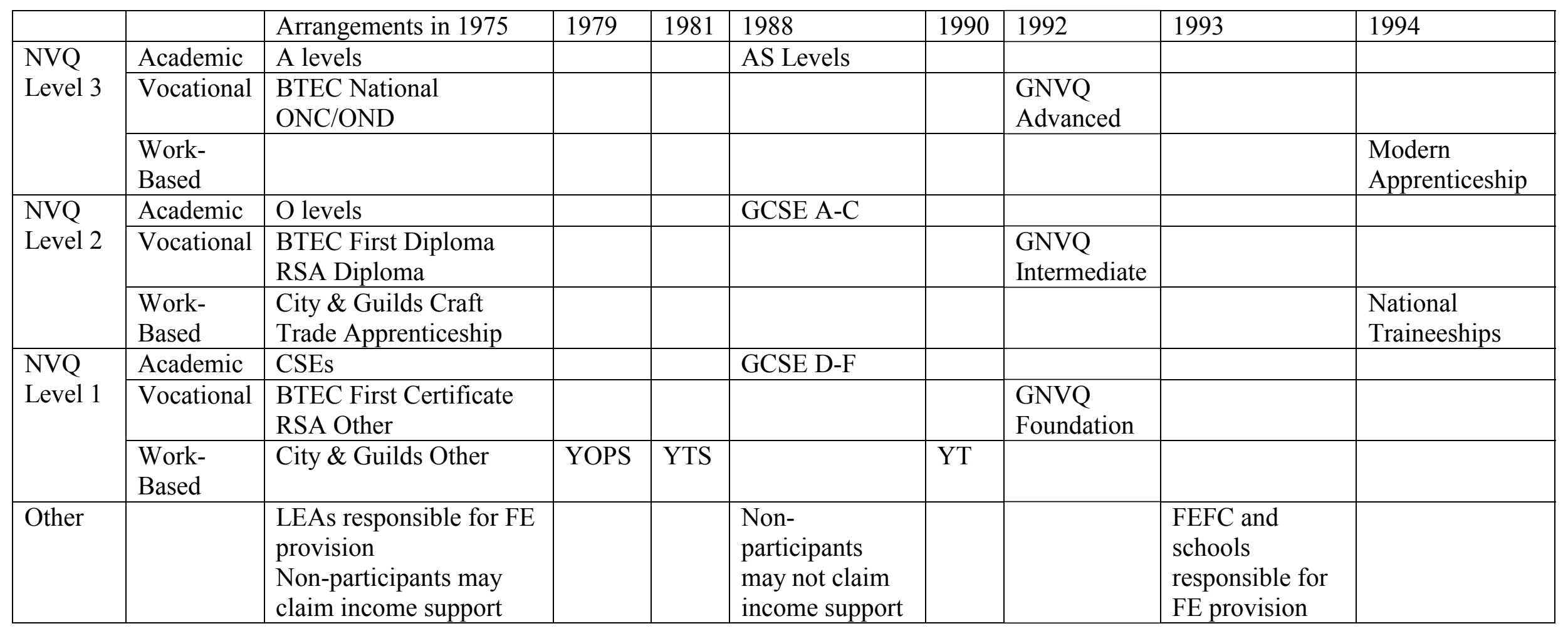

Notes: Compiled by the author from various sources. NVQ = National Vocational Qualification; BTEC = Business Technology and Education Council; RSA = Royal Society of Arts; YOPS = Youth Opportunities Scheme, YTS = Youth Training Scheme; YT = Youth Training; GNVQ= General National Vocational Qualification; FEFC = Further Education Funding Council. 
Table 2: FE Participation Assumptions from Highest Qualification in the LFS \& GHS

\begin{tabular}{|c|c|c|c|}
\hline & Leave & Participate-Vocational & Participate-Academic \\
\hline GHS & $\begin{array}{l}\text { O levels } \\
\text { CSE } \\
\text { None }\end{array}$ & $\begin{array}{l}\text { HNC/HND; Nursing } \\
\text { ONC/OND; } \\
\text { RSA equivalent; } \\
\text { Apprenticeship }\end{array}$ & $\begin{array}{l}\text { Higher Degree } \\
\text { Teaching } \\
\text { A levels }\end{array}$ \\
\hline $\begin{array}{l}\text { LFS } \\
1979- \\
1984\end{array}$ & $\begin{array}{l}\text { O levels } \\
\text { CSE; Still Study; } \\
\text { None; Unknown; } \\
\text { N/A }\end{array}$ & $\begin{array}{l}\text { Corp/Prof qual; Nursing; } \\
\text { HNC/HND; ONC/OND; } \\
\text { C\&G } \\
\text { Other Prof/Voc qual }\end{array}$ & $\begin{array}{l}\text { First/Higher Degree; } \\
\text { Teaching (Sec); } \\
\text { Teaching (Pri); A } \\
\text { level }\end{array}$ \\
\hline $\begin{array}{l}\text { LFS } \\
1985- \\
1988\end{array}$ & See above & $\begin{array}{l}\text { Other Degree; Nursing; } \\
\text { BTEC Higher/HND/HNC; } \\
\text { BTEC Lower/ONC/OND; } \\
\text { C\&G; Any other Prof/Voc } \\
\text { qual }\end{array}$ & See above \\
\hline $\begin{array}{l}\text { LFS } \\
1989- \\
1991\end{array}$ & See above & $\begin{array}{l}\text { Other Degree; Nursing; } \\
\text { BTEC Higher/HND/HNC; } \\
\text { BTEC Lower/ONC/OND; } \\
\text { C\&G; YTS; Other Prof/Voc } \\
\text { qual }\end{array}$ & See above \\
\hline $\begin{array}{l}\text { LFS } \\
1992\end{array}$ & See above & $\begin{array}{l}\text { Other Degree; Nursing; } \\
\text { BTEC Higher/HND/HNC; } \\
\text { BTEC Lower/ONC/OND; } \\
\text { C\&G; YTS; RSA } \\
\text { Other Prof/Voc qual }\end{array}$ & See above \\
\hline $\begin{array}{l}\text { LFS } \\
1993- \\
1996\end{array}$ & $\begin{array}{l}\text { GCSE } \\
\text { (A-C) } \\
\text { GCSE (D-F); } \\
\text { CSE; None; } \\
\text { Don't Know }\end{array}$ & $\begin{array}{l}\text { Other Degree; Nursing; } \\
\text { BTEC Higher/HND/HNC; } \\
\text { RSA Higher; RSA } \\
\text { Advanced; BTEC } \\
\text { Lower/ONC/OND; C\&G } \\
\text { Ad; CSYS; CSYS; RSA } \\
\text { Diploma; C\&G Craft; BTEC } \\
\text { First; BTEC General; YT; } \\
\text { YTP; SCOTVEC; RSA } \\
\text { other; C\&G other; Other Prof } \\
\text { qual }\end{array}$ & $\begin{array}{l}\text { Higher Degree; First } \\
\text { Degree; Diploma in } \\
\text { HE; Teaching; Other } \\
\text { High Qual below } \\
\text { degree level; A level; } \\
\text { SCE }\end{array}$ \\
\hline
\end{tabular}

Notes: GHS = General Household Survey; LFS = Labour Force Survey 
Table 3: Variable Means by Selected Regions 1976-1996

\begin{tabular}{|l|c|c|c|c|c|c|}
\hline & NORTH & YORKS & W-MID & E-ANG & S-EAST & S-WEST \\
\hline Participation (FT) & 44.027 & 46.696 & 49.564 & 49.866 & 58.214 & 54.216 \\
\hline$>=5$ A-C & 22.608 & 22.523 & 23.106 & 25.829 & 27.565 & 27.131 \\
\hline $1-4$ A-C & 27.799 & 26.840 & 28.128 & 28.693 & 28.379 & 29.516 \\
\hline$>=1$ Pass & 35.206 & 35.462 & 33.522 & 32.247 & 29.156 & 31.613 \\
\hline No Passes & 13.576 & 14.339 & 14.521 & 11.624 & 11.146 & 9.381 \\
\hline Avg Household Income & 2.130 & 2.142 & 2.165 & 2.323 & 2.665 & 2.284 \\
\hline Unemployment (18-19) & 0.187 & 0.149 & 0.155 & 0.102 & 0.102 & 0.111 \\
\hline Unemployment (Leave) & 0.126 & 0.104 & 0.111 & 0.074 & 0.082 & 0.079 \\
\hline Unemployment (Part-Voc) & 0.085 & 0.064 & 0.071 & 0.054 & 0.057 & 0.052 \\
\hline Unemployment (Part-Ac) & 0.058 & 0.048 & 0.049 & 0.042 & 0.047 & 0.051 \\
\hline Return (Part-Voc) & 0.218 & 0.191 & 0.173 & 0.202 & 0.157 & 0.212 \\
\hline Return (Part-Ac) & 0.367 & 0.343 & 0.370 & 0.380 & 0.380 & 0.373 \\
\hline Cohort Size (000) & 42.35 & 65.63 & 70.32 & 23.85 & 202.82 & 53.77 \\
\hline
\end{tabular}

Notes: Authors calculations. 
Table 4: Participation Amongst Boys

\begin{tabular}{|c|c|c|c|c|c|c|}
\hline & Basic & \multicolumn{2}{|c|}{ Sensitivity Checks } & \multirow{2}{*}{$\begin{array}{c}\text { Region- } \\
\text { Specific } \\
\text { Trends } \\
(4)\end{array}$} & \multicolumn{2}{|c|}{ Reduced-Form Models } \\
\hline & (1) & (2) & (3) & & (5) & (6) \\
\hline Exam5 & $\begin{array}{c}0.961 \\
(0.160)\end{array}$ & $\begin{array}{c}1.057 \\
(0.160)\end{array}$ & $\begin{array}{c}1.060 \\
(0.176)\end{array}$ & $\begin{array}{c}0.445 \\
(0.202)\end{array}$ & & \\
\hline Exam4 & $\begin{array}{c}0.414 \\
(0.149)\end{array}$ & $\begin{array}{c}0.475 \\
(0.142)\end{array}$ & $\begin{array}{c}0.388 \\
(0.158)\end{array}$ & $\begin{array}{l}0.0318 \\
(0.156)\end{array}$ & & \\
\hline Exam1 & $\begin{array}{c}0.414 \\
(0.151)\end{array}$ & $\begin{array}{c}0.433 \\
(0.157)\end{array}$ & $\begin{array}{c}0.594 \\
(0.169)\end{array}$ & $\begin{array}{c}0.196 \\
(0.155)\end{array}$ & & \\
\hline Income & $\begin{array}{c}0.743 \\
(1.228)\end{array}$ & $\begin{array}{c}1.130 \\
(0.965)\end{array}$ & $\begin{array}{c}3.463 \\
(1.640)\end{array}$ & $\begin{array}{l}-1.122 \\
(1.128)\end{array}$ & $\begin{array}{c}1.292 \\
(1.321)\end{array}$ & $\begin{array}{l}-1.175 \\
(1.124)\end{array}$ \\
\hline $\begin{array}{l}\text { Unemp } \\
\text { (Youth) }\end{array}$ & $\begin{array}{c}0.683 \\
(0.109) \\
\end{array}$ & $\begin{array}{c}0.518 \\
(0.109) \\
\end{array}$ & $\begin{array}{c}0.599 \\
(0.105) \\
\end{array}$ & $\begin{array}{c}0.490 \\
(0.138) \\
\end{array}$ & $\begin{array}{c}0.793 \\
(0.116) \\
\end{array}$ & $\begin{array}{c}0.453 \\
(0.138) \\
\end{array}$ \\
\hline $\begin{array}{l}\text { Unemp } \\
\text { (Leave) }\end{array}$ & $\begin{array}{c}-0.083 \\
(0.124)\end{array}$ & $\begin{array}{l}-0.0719 \\
(0.116)\end{array}$ & $\begin{array}{c}-0.0614 \\
(0.139)\end{array}$ & $\begin{array}{l}-0.0905 \\
(0.114)\end{array}$ & $\begin{array}{l}-0.779 \\
(0.129)\end{array}$ & $\begin{array}{c}-0.0434 \\
(0.111)\end{array}$ \\
\hline $\begin{array}{l}\text { Unemp } \\
\text { (Voc) }\end{array}$ & $\begin{array}{l}-0.146 \\
(0.153) \\
\end{array}$ & $\begin{array}{c}0.124 \\
(0.155) \\
\end{array}$ & $\begin{array}{l}0.0247 \\
(0.247) \\
\end{array}$ & $\begin{array}{c}-0.0804 \\
(0.152) \\
\end{array}$ & $\begin{array}{c}-0.281 \\
(0.183) \\
\end{array}$ & $\begin{array}{c}-0.0776 \\
(0.153) \\
\end{array}$ \\
\hline $\begin{array}{l}\text { Unemp } \\
(\mathrm{Ac})\end{array}$ & $\begin{array}{c}0.118 \\
(0.112) \\
\end{array}$ & $\begin{array}{c}0.200 \\
(0.113) \\
\end{array}$ & $\begin{array}{c}0.455 \\
(0.188) \\
\end{array}$ & $\begin{array}{c}0.0990 \\
(0.0978) \\
\end{array}$ & $\begin{array}{c}0.110 \\
(0.134) \\
\end{array}$ & $\begin{array}{c}0.121 \\
(0.101) \\
\end{array}$ \\
\hline $\begin{array}{l}\text { Return } \\
\text { (Ac) }\end{array}$ & $\begin{array}{c}1.135 \\
(1.779)\end{array}$ & $\begin{array}{c}-0.204 \\
(1.635) \\
\end{array}$ & $\begin{array}{c}0.513 \\
(3.176)\end{array}$ & $\begin{array}{c}1.266 \\
(1.612)\end{array}$ & $\begin{array}{c}1.911 \\
(2.184)\end{array}$ & $\begin{array}{c}1.972 \\
(1.635)\end{array}$ \\
\hline $\begin{array}{l}\text { Return } \\
\text { (Voc) }\end{array}$ & $\begin{array}{c}-3.112 \\
(2.504)\end{array}$ & $\begin{array}{l}-0.975 \\
(1.501) \\
\end{array}$ & $\begin{array}{l}-5.809 \\
(2.954)\end{array}$ & $\begin{array}{l}-3.016 \\
(2.384) \\
\end{array}$ & $\begin{array}{l}-4.016 \\
(3.019) \\
\end{array}$ & $\begin{array}{l}-3.258 \\
(2.314) \\
\end{array}$ \\
\hline $\begin{array}{l}\text { Cohort } \\
\text { Size }\end{array}$ & $\begin{array}{l}-0.066 \\
(0.018) \\
\end{array}$ & $\begin{array}{l}-0.056 \\
(0.022) \\
\end{array}$ & $\begin{array}{c}-0.032 \\
(0.023) \\
\end{array}$ & $\begin{array}{c}-0.042 \\
(0.0333) \\
\end{array}$ & $\begin{array}{c}-0.063 \\
(0.016) \\
\end{array}$ & $\begin{array}{c}.0487 \\
(0.0293) \\
\end{array}$ \\
\hline $\begin{array}{l}\text { Region } \\
\text { \& Time }\end{array}$ & $\sqrt{ }$ & $\sqrt{ }$ & $\sqrt{ }$ & $\sqrt{ }$ & $\sqrt{ }$ & $\sqrt{ }$ \\
\hline $\begin{array}{l}\text { Region } \\
\text { Trends }\end{array}$ & & & & $\sqrt{ }$ & & $\sqrt{ }$ \\
\hline $\mathrm{N}$ & 136 & 144 & 128 & 136 & 136 & 136 \\
\hline R-sq & 0.99 & 0.99 & 0.99 & 0.99 & 0.99 & 0.99 \\
\hline
\end{tabular}

Notes: In column (1), variables subject to sampling error are instrumented using lagged values as instruments. In column (2) and (3), levels and three-year moving averages are used respectively. In columns (4), (5) and (6), these variables are treated as in column (1). Robust standard errors in parentheses. 
Table 5: Participation Amongst Girls

\begin{tabular}{|c|c|c|c|c|c|c|}
\hline & $\begin{array}{l}\text { Basic } \\
\text { Model }\end{array}$ & \multicolumn{2}{|c|}{ Sensitivity Checks } & \multirow{2}{*}{$\begin{array}{l}\text { Region- } \\
\text { Specific } \\
\text { Trends } \\
(4)\end{array}$} & \multicolumn{2}{|c|}{$\begin{array}{l}\text { Reduced Form } \\
\text { Models }\end{array}$} \\
\hline & (1) & (2) & (3) & & (5) & (6) \\
\hline Exam5 & $\begin{array}{c}0.684 \\
(0.248)\end{array}$ & $\begin{array}{c}0.563 \\
(0.223)\end{array}$ & $\begin{array}{c}0.697 \\
(0.263)\end{array}$ & $\begin{array}{c}0.769 \\
(0.294)\end{array}$ & & \\
\hline Exam4 & $\begin{array}{l}-0.419 \\
(0.215)\end{array}$ & $\begin{array}{l}-0.469 \\
(0.186)\end{array}$ & $\begin{array}{l}-0.314 \\
(0.219)\end{array}$ & $\begin{array}{l}0.0404 \\
(0.172)\end{array}$ & & \\
\hline Exam1 & $\begin{array}{l}-0.302 \\
(0.221)\end{array}$ & $\begin{array}{l}-0.289 \\
(0.205)\end{array}$ & $\begin{array}{l}-0.180 \\
(0.232)\end{array}$ & $\begin{array}{l}0.0250 \\
(0.154)\end{array}$ & & \\
\hline Income & $\begin{array}{l}-0.046 \\
(1.103)\end{array}$ & $\begin{array}{c}1.053 \\
(0.849)\end{array}$ & $\begin{array}{l}-0.170 \\
(2.046)\end{array}$ & $\begin{array}{c}0.215 \\
(0.999)\end{array}$ & $\begin{array}{c}1.708 \\
(1.399)\end{array}$ & $\begin{array}{c}0.125 \\
(1.056)\end{array}$ \\
\hline $\begin{array}{l}\text { Unemp } \\
\text { (Youth) }\end{array}$ & $\begin{array}{c}0.219 \\
(0.0863)\end{array}$ & $\begin{array}{c}0.225 \\
(0.0686)\end{array}$ & $\begin{array}{c}0.433 \\
(0.166)\end{array}$ & $\begin{array}{c}0.211 \\
(0.115)\end{array}$ & $\begin{array}{c}0.516 \\
(0.121)\end{array}$ & $\begin{array}{c}0.277 \\
(0.114)\end{array}$ \\
\hline $\begin{array}{l}\text { Unemp } \\
\text { (Leave) }\end{array}$ & $\begin{array}{l}-0.171 \\
(0.168)\end{array}$ & $\begin{array}{c}0.221 \\
(0.182)\end{array}$ & $\begin{array}{l}-0.393 \\
(0.294)\end{array}$ & $\begin{array}{l}-0.253 \\
(0.157)\end{array}$ & $\begin{array}{c}0.111 \\
(0.220)\end{array}$ & $\begin{array}{l}-0.0461 \\
(0.141)\end{array}$ \\
\hline $\begin{array}{l}\text { Unemp } \\
\text { (Voc) }\end{array}$ & $\begin{array}{c}0.121 \\
(0.111)\end{array}$ & $\begin{array}{l}-0.0998 \\
(0.132)\end{array}$ & $\begin{array}{l}-0.073 \\
(0.261)\end{array}$ & $\begin{array}{c}0.214 \\
(0.0976)\end{array}$ & $\begin{array}{c}-0.00689 \\
(0.142)\end{array}$ & $\begin{array}{c}0.191 \\
(0.987)\end{array}$ \\
\hline $\begin{array}{l}\text { Unemp } \\
\text { (Ac) }\end{array}$ & $\begin{array}{l}-0.151 \\
(0.109)\end{array}$ & $\begin{array}{l}-0.00294 \\
(0.0874)\end{array}$ & $\begin{array}{l}-0.196 \\
(0.174)\end{array}$ & $\begin{array}{l}0.0260 \\
(0.103)\end{array}$ & $\begin{array}{l}-0.0231 \\
(0.123)\end{array}$ & $\begin{array}{c}0.116 \\
(0.0959)\end{array}$ \\
\hline $\begin{array}{l}\text { Return } \\
(\mathrm{Ac})\end{array}$ & $\begin{array}{l}-0.138 \\
(0.784)\end{array}$ & $\begin{array}{l}-0.133 \\
(0.875)\end{array}$ & $\begin{array}{l}-9.705 \\
(1.560)\end{array}$ & $\begin{array}{c}0.469 \\
(0.585)\end{array}$ & $\begin{array}{l}0.0155 \\
(1.098)\end{array}$ & $\begin{array}{c}0.866 \\
(0.615)\end{array}$ \\
\hline $\begin{array}{l}\text { Return } \\
\text { (Voc) }\end{array}$ & $\begin{array}{c}0.904 \\
(1.359)\end{array}$ & $\begin{array}{l}-0.118 \\
(0.335)\end{array}$ & $\begin{array}{c}0.139 \\
(0.685)\end{array}$ & $\begin{array}{c}0.932 \\
(0.904)\end{array}$ & $\begin{array}{c}2.074 \\
(1.599)\end{array}$ & $\begin{array}{c}2.073 \\
(0.998)\end{array}$ \\
\hline $\begin{array}{l}\text { Cohort } \\
\text { Size }\end{array}$ & $\begin{array}{l}-0.061 \\
(0.028)\end{array}$ & $\begin{array}{l}-0.0366 \\
(0.024)\end{array}$ & $\begin{array}{l}-0.051 \\
(0.033)\end{array}$ & $\begin{array}{c}-0.157 \\
(0.0372)\end{array}$ & $\begin{array}{c}0.032 \\
(0.023)\end{array}$ & $\begin{array}{c}-0.145 \\
(0.0437)\end{array}$ \\
\hline $\begin{array}{l}\text { Region } \\
\& \text { Time }\end{array}$ & $\sqrt{ }$ & $\sqrt{ }$ & $\sqrt{ }$ & $\sqrt{ }$ & $\sqrt{ }$ & $\sqrt{ }$ \\
\hline $\begin{array}{l}\text { Region } \\
\text { Trends }\end{array}$ & & & & $\sqrt{ }$ & & $\sqrt{ }$ \\
\hline $\mathrm{N}$ & 136 & 144 & 128 & 136 & 136 & 136 \\
\hline R-sq & 0.99 & 0.99 & 0.99 & 0.99 & 0.99 & 0.99 \\
\hline
\end{tabular}

Notes: Robust standard errors in parentheses. 
Table 6: Modelling the Estimated Year Dummy Variables

\begin{tabular}{|c|c|c|c|c|}
\hline & \multicolumn{2}{|c|}{ Without Regional Trends } & \multicolumn{2}{|c|}{ With Regional Trends } \\
\hline & (1) & (2) & (3) & (4) \\
\hline & \multicolumn{4}{|c|}{ Boys } \\
\hline $\begin{array}{l}\text { Returns } \\
\text { (Voc) }\end{array}$ & $\begin{array}{c}-7.648 \\
(17.294) \\
\end{array}$ & $\begin{array}{l}-0.0955 \\
(0.0774 \\
\end{array}$ & $\begin{array}{c}-18.697 \\
(16.992) \\
\end{array}$ & $\begin{array}{c}-0.0734 \\
(0.0358) \\
\end{array}$ \\
\hline $\begin{array}{l}\text { Returns } \\
\text { (Ac) }\end{array}$ & $\begin{array}{c}59.624 \\
(29.910)\end{array}$ & $\begin{array}{c}212.87 \\
(30.288)\end{array}$ & $\begin{array}{c}2.875 \\
(29.740)\end{array}$ & $\begin{array}{c}164.11 \\
(15.677)\end{array}$ \\
\hline $\begin{array}{l}\text { Unemp } \\
\text { (Leave) }\end{array}$ & $\begin{array}{l}-4.600 \\
(0.880)\end{array}$ & $\begin{array}{l}-1.725 \\
(0.682)\end{array}$ & $\begin{array}{l}-4.465 \\
(0.954)\end{array}$ & $\begin{array}{l}-1.398 \\
(0.312) \\
\end{array}$ \\
\hline $\begin{array}{l}\text { Unemp } \\
\text { (Voc) }\end{array}$ & $\begin{array}{c}4.773 \\
(1.238)\end{array}$ & $\begin{array}{c}0.00323 \\
(0.00595)\end{array}$ & $\begin{array}{c}5.517 \\
(1.305)\end{array}$ & $\begin{array}{c}0.00281 \\
(0.00272)\end{array}$ \\
\hline $\begin{array}{l}\text { Unemp } \\
\text { (Ac) }\end{array}$ & $\begin{array}{c}0.234 \\
(0.135)\end{array}$ & $\begin{array}{l}-0.195 \\
(0.174)\end{array}$ & $\begin{array}{l}0.0516 \\
(0.134)\end{array}$ & $\begin{array}{c}-0.184 \\
(0.0803)\end{array}$ \\
\hline $\mathrm{N}$ & 17 & 17 & 16 & 16 \\
\hline \multirow[t]{2}{*}{ R-sq. } & 0.915 & 0.856 & 0.832 & 0.939 \\
\hline & \multicolumn{4}{|c|}{ Girls } \\
\hline $\begin{array}{l}\text { Returns } \\
\text { (Voc) }\end{array}$ & $\begin{array}{l}-17.361 \\
(14.819) \\
\end{array}$ & $\begin{array}{c}-0.128 \\
(0.0656)\end{array}$ & $\begin{array}{c}-43.018 \\
(30.306) \\
\end{array}$ & $\begin{array}{c}-0.224 \\
(0.0686)\end{array}$ \\
\hline $\begin{array}{l}\text { Returns } \\
\text { (Ac) }\end{array}$ & $\begin{array}{c}30.104 \\
(19.156)\end{array}$ & $\begin{array}{l}-35.609 \\
(41.645)\end{array}$ & $\begin{array}{c}55.323 \\
(38.520)\end{array}$ & $\begin{array}{c}-49.609 \\
(42.958)\end{array}$ \\
\hline $\begin{array}{l}\text { Unemp } \\
\text { (Leave) }\end{array}$ & $\begin{array}{l}-2.107 \\
(0.955) \\
\end{array}$ & $\begin{array}{l}-2.255 \\
(0.904) \\
\end{array}$ & $\begin{array}{c}-2.897 \\
(1.840)\end{array}$ & $\begin{array}{l}-4.536 \\
(0.957)\end{array}$ \\
\hline $\begin{array}{l}\text { Unemp } \\
\text { (Voc) }\end{array}$ & $\begin{array}{c}1.767 \\
(1.268)\end{array}$ & $\begin{array}{c}0.00120 \\
(0.00419)\end{array}$ & $\begin{array}{c}1.041 \\
(2.456)\end{array}$ & $\begin{array}{r}-0.000212 \\
(0.00432)\end{array}$ \\
\hline $\begin{array}{l}\text { Unemp } \\
\text { (Ac) }\end{array}$ & $\begin{array}{l}0.1382 \\
(0.136)\end{array}$ & $\begin{array}{c}0.250 \\
(0.171)\end{array}$ & $\begin{array}{c}0.325 \\
(0.269) \\
\end{array}$ & $\begin{array}{c}0.294 \\
(0.177)\end{array}$ \\
\hline $\mathrm{N}$ & 17 & 17 & 16 & 16 \\
\hline R-sq. & 0.595 & 0.685 & 0.612 & 0.913 \\
\hline
\end{tabular}

Notes: Dependent variables are the estimated dummy variables from specifications (1) and (4) of Tables 4 and 5. Standard errors in parentheses. 
Table 7: Decomposition of Changes in Full-Time Participation

\begin{tabular}{|c|c|c|c|c|c|c|c|c|}
\hline & \multicolumn{2}{|c|}{ 1981-1988 } & \multicolumn{2}{|c|}{ 1988-1993 } & \multicolumn{2}{|c|}{ 1993-1996 } & \multicolumn{2}{|c|}{$1996-2001$} \\
\hline & (1) & (2) & (3) & (4) & $(5)$ & (6) & (7) & $(8)$ \\
\hline \multicolumn{9}{|c|}{ Boys } \\
\hline Exam5 & 2.327 & 1.077 & 11.588 & 5.363 & 3.824 & 1.76 & 4.315 & 1.997 \\
\hline Exam4 & -0.045 & -0.003 & 0.027 & 0.0021 & -0.685 & -0.056 & -0.254 & -0.019 \\
\hline Exam1 & -0.559 & -0.246 & -1.424 & -0.674 & -1.126 & -0.533 & -0.878 & -0.416 \\
\hline Income & 0.356 & -0.537 & -0.062 & 0.0939 & -0.011 & 0.0173 & & \\
\hline Un (Youth) & -2.647 & -1.897 & 6.318 & 4.529 & -3.074 & -2.203 & -6.181 & -4.431 \\
\hline Un (Leave) & -0.012 & -0.014 & -0.249 & -0.273 & 0.229 & 0.251 & & \\
\hline Un (Voc) & -0.012 & -0.006 & -0.530 & -0.292 & 0.280 & 0.155 & & \\
\hline Un (Ac) & -0.019 & -0.016 & 0.242 & 0.204 & -0.187 & -0.157 & & \\
\hline Return (Voc) & -0.276 & -0.267 & -0.216 & -0.210 & 0.105 & 0.102 & & \\
\hline Return (Ac) & -0.014 & -0.016 & 0.059 & 0.0652 & 0.007 & 0.0083 & & \\
\hline Cohort & 0.447 & 0.248 & 1.223 & 0.779 & -0.551 & -0.351 & -0.232 & -0.148 \\
\hline Time & 4.415 & -3.955 & 5.325 & 7.961 & 0.381 & -3.591 & & \\
\hline Trend & & 10.606 & & 6.485 & & 5.321 & & 6.651 \\
\hline Total & 3.962 & 4.991 & 22.301 & 24.033 & -0.807 & 0.735 & -3.231 & -3.018 \\
\hline Actual & \multicolumn{2}{|c|}{3.409} & \multicolumn{2}{|c|}{22.864} & \multicolumn{2}{|c|}{-0.916} & \multicolumn{2}{|c|}{$\sim 0$} \\
\hline & & & & & & & & \\
\hline \multicolumn{9}{|c|}{ Girls } \\
\hline Exam5 & 2.607 & 2.929 & 12.574 & 14.13 & 2.770 & 3.113 & 3.842 & 4.318 \\
\hline Exam4 & -0.283 & 0.0273 & -0.277 & 0.0267 & 0.804 & -0.0775 & 1.176 & -0.113 \\
\hline Exam1 & 1.199 & -0.099 & 3.074 & -0.255 & 0.901 & -0.0746 & 0.372 & -0.0308 \\
\hline Income & -0.022 & 0.103 & 0.004 & -0.0180 & 0.001 & -0.0033 & & \\
\hline Youth U/e & -0.656 & -0.634 & 0.875 & 0.845 & -0.519 & -0.5018 & -1.094 & -1.056 \\
\hline U/e (Leave) & -0.484 & -0.719 & 0.312 & 0.464 & 0.188 & 0.2793 & & \\
\hline U/e (Voc) & 0.203 & 0.3611 & -0.044 & -0.0781 & -0.045 & -0.0807 & & \\
\hline $\mathrm{U} / \mathrm{e}(\mathrm{Ac})$ & -0.192 & 0.033 & 0.105 & -0.0181 & 0.180 & -0.031 & & \\
\hline Return (Voc) & -0.019 & -0.02 & 0.141 & 0.145 & -0.058 & -0.0596 & & \\
\hline Return (Ac) & 0.016 & -0.054 & -0.012 & 0.0411 & 0.008 & -0.027 & & \\
\hline Cohort & 0.413 & 1.070 & 1.130 & 2.929 & -0.509 & -1.319 & -0.215 & -0.558 \\
\hline Time & -3.630 & -6.686 & 6.093 & 3.553 & -3.373 & -2.04 & & \\
\hline Trend & & 2.331 & & 1.772 & & -0.824 & & 1.465 \\
\hline Total & -0.850 & -1.356 & 23.975 & 23.537 & 0.348 & 0.348 & 4.082 & 4.026 \\
\hline Actual & \multicolumn{2}{|c|}{-0.861} & \multicolumn{2}{|c|}{24.278} & \multicolumn{2}{|c|}{0.223} & \multicolumn{2}{|c|}{$\sim 0$} \\
\hline
\end{tabular}

Notes: Predicted changes based on columns (1) and (4) of Tables 4 and 5. Data for change in exam achievement and cohort size from Statistical Bulletins 8/99, Table 1 and Statistical First Release 45/2001, Table 1. Data for change in youth unemployment from Labour Market Trends, March 2001, Table 5.21. 


\section{IZA Discussion Papers}

No. Author(s)

534

535

536

537

538
A. M. Stiglbauer
F. Stahl
R. Winter-Ebmer
J. Zweimüller

E. Wasmer

G. S. Epstein I. N. Gang

M. Frölich
Title

Area

Date

The Insider-Outsider Theory: A Survey

3

07/02

Wage Determination and the Sources of

3

07/02

Bargaining Power

Pension Taxes versus Early Retirement Rights

3

07/02

Unemployment Vouchers versus Low-Wage

3

07/02

Subsidies

The Pension Transfer Program

07/02

Labour-Market Institutions and Macroeconomic

3

07/02

Shocks

High Skilled Migration and the Exertion of Effort 1

08/02 by the Local Population

Do the Higher Educated Unemployed Crowd Out 2 the Lower Educated Ones in a Competition for Jobs

Programme Evaluation with Multiple Treatments 6

08/02

Wages, Productivity, and Work Intensity in the 5

$08 / 02$

Great Depression

Disentangling the Minimum Wage Puzzle: An

3

$08 / 02$

Analysis of Worker Accessions and Separations

The Role of Background Factors for Reading

6

08/02 2000 Study

Job Creation and Job Destruction in a Regulated

2

08/02 Labor Market: The Case of Austria

What is the Value of Knowing the Propensity

Score for Estimating Average Treatment

Effects?

Interpreting Europe and US Labor Markets

2

08/02

Differences: The Specificity of Human Capital Investments

The Impact of Local Labour Market Conditions on Participation in Further Education in England 